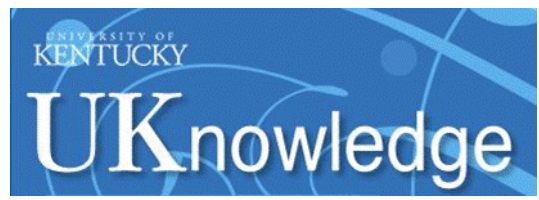

University of Kentucky

UKnowledge

Institute for the Study of Free Enterprise

Working Papers

Institute for the Study of Free Enterprise

5-2017

\title{
Single Bidders and Tacit Collusion in Highway Procurement Auctions
}

David R. Barrus

Brigham Young University-Idaho, davidbarrus@gmail.com

Frank A. Scott Jr.

University of Kentucky, FSCOTT@UKY.EDU

Follow this and additional works at: https://uknowledge.uky.edu/isfe_papers

Part of the Public Economics Commons

Right click to open a feedback form in a new tab to let us know how this document benefits you.

\section{Repository Citation}

Barrus, David R. and Scott, Frank A. Jr., "Single Bidders and Tacit Collusion in Highway Procurement Auctions" (2017). Institute for the Study of Free Enterprise Working Papers. 22.

https://uknowledge.uky.edu/isfe_papers/22

This Research Paper is brought to you for free and open access by the Institute for the Study of Free Enterprise at UKnowledge. It has been accepted for inclusion in Institute for the Study of Free Enterprise Working Papers by an authorized administrator of UKnowledge. For more information, please contact UKnowledge@lsv.uky.edu. 


\title{
Single Bidders and Tacit Collusion in Highway Procurement Auctions
}

\section{David Barrus \\ Frank Scott}

May 2017

Institute for the Study of Free Enterprise

Working Paper 7

\author{
University of Kentucky \\ 244 Gatton College of Business and Economics \\ Lexington, KY 40506-0034 \\ http://isfe.uky.edu/
}


Barrus, David and Frank Scott. "Single Bidders and Tacit Collusion in Highway Procurement Auctions." Schnatter Institute Working Paper. John H. Schnatter Institute for the Study of Free Enterprise, University of Kentucky, Lexington, KY, May 2017.

\begin{abstract}
Collusion in auctions can take different forms, one of which is refraining from bidding. Such behavior may be overt or tacit. Certain aspects of highway procurement auctions facilitate collusive outcomes. We collect data on asphalt paving auctions conducted by the Kentucky Transportation Cabinet from 2005 to 2007 . We analyze both the bid participation decision and the pricing decision. We include variables that affect firm's' costs as well as variables that capture competitive and strategic effects. Most importantly, we determine the potential service area of each asphalt plant and use that information to determine the potential bidders for each paving project. We find that, in geographic markets with only a few feasible suppliers, county boundaries serve as a coordinating mechanism for softening competition, significantly influencing firms' decisions whether and how much to bid.
\end{abstract}

\author{
David Barrus \\ Brigham Young University-Idaho \\ Department of Economics \\ Rexburg, ID 83460-0815 \\ Frank Scott \\ University of Kentucky \\ Gatton College of Business and Economics \\ Department of Economics \\ Lexington, KY 40506-0034 \\ fscott@uky.edu
}

Keywords: Kentucky, competition, information, highways

Schnatter Institute Working Papers are circulated for discussion and comment purposes. They have not been peer reviewed through the institute. Working Papers present an author's provisional findings, which, upon further revision, are likely to be republished in an academic journal. The opinions expressed in Schnatter Institute Working Papers reflect the views of the authors and may not represent the opinions of the Schnatter Institute or the University of Kentucky. 


\title{
Single Bidders and Tacit Collusion in Highway Procurement Auctions
}

\author{
David Barrus and Frank Scott
}

People of the same trade seldom meet together, even for merriment and diversion, but the conversation ends in a conspiracy against the public, or in some contrivance to raise prices. ${ }^{2}$

BID LETTING FOR JANUARY 21, 2005 PARTS 1, 2, \& 3: Have been advertised with 56 projects consisting of grade and drain with asphalt surface, guardrail, asphalt resurfacing, right-of-way mowing and litter removal, slide repair, fine turf mowing, bridge painting and cleaning, bridge deck restoration and waterproofing, culvert replacement, etc. Letting eve activities will be held at the Marriott's Griffin Gate Resort in Lexington...Please note the attached revised reservation form from the Marriott Griffin Gate for the 2005 Kentucky Association of Highway Contractors Bid Lettings. ${ }^{3}$

Understanding firms' attempts to collude drives much of economists' study of oligopoly.

Detection and deterrence of collusion are perhaps the primary challenges of antitrust policy. ${ }^{4}$ In auction markets, collusion has attracted less attention than a general focus on design mechanisms and other factors affecting the competitiveness of such markets. ${ }^{5}$ Much of the attention paid to collusion in auction markets has been motivated by price fixing and bid-rigging conspiracies in public procurement auctions. ${ }^{6}$

Bid-rigging schemes can take a variety of forms. Sometimes all participants in an auction are part of an overt conspiracy, and then the challenge becomes determining which conspirator will win the auction and how other conspirators will be compensated. Things change somewhat if non-conspirators participate in the auction. Accommodating behavior by co-conspirators often

\footnotetext{
${ }^{2}$ Smith (1776), Book I, Ch. X, Part II.

${ }^{3}$ Kentucky Association of Highway Contractors newsletter: Highway Highlights, January 18, 2005.

${ }^{4}$ Porter (2005), p. 147.

${ }^{5}$ See, for example, Klemperer (2004).

${ }^{6}$ Hendricks, McAfee, and Williams (2015) provide an overview of this literature.
} 
takes the form of submitting complementary bids above (in a procurement auction) the predetermined winner's bid. If the collusive behavior is overt, it violates federal antitrust laws in the United States. ${ }^{7}$

Various methods have been proposed for detecting collusion in auction markets. As Harrington (2008), Porter and Zona (1993), and others have noted, however, refraining from bidding is another form that collusion may take. Such behavior may be overt, if it is the result of explicit communication among firms, or tacit, if it arises without overt behavior. While overt agreements not to bid have been the object of study, we are not aware of any empirical analysis of tacit refusals to bid in procurement auctions.

During the 1980s there were hundreds of bid-rigging prosecutions and convictions in public procurement auctions across the country. ${ }^{8}$ Since then, government officials have aggressively monitored bidding behavior, and there has been a relatively reduced emphasis on $\S 1$ Sherman Act prosecutions since the 1980s. That does not mean that concerns over the competitiveness of bidding, especially in highway procurement auctions, have gone away. Instead, the trend has been toward single-bidder auctions, with resulting higher prices for public transportation projects. ${ }^{9}$

The difference that a second bidder can make in highway procurement auctions is sizable. As can be seen in Table 1, in Kentucky during the 2005-07 period 64 percent of asphalt paving projects only had one bidder, and 91 percent had one or two bidders. Winning bids for single-bid asphalt projects averaged 2.20 percent above the state highway engineer's estimate of the cost of the job. Winning bids when there were two bidders averaged 13.62 percent below the engineer's

\footnotetext{
${ }^{7}$ Werden (2004) extensively discusses the definition and proof of collusive agreements under the antitrust laws.

${ }^{8}$ USGAO (1990): http://archive.gao.gov/d22t8/142779.pdf.

${ }^{9}$ AASHTO/FHWA Survey on Construction Cost Increases and Competition, April 2006.
} 
estimate, and with three bidders the low bid averaged 16.82 percent below the engineer's estimate. It is clear that even a single other bidder sharply constrains a firm's ability to raise prices. The nearly 16 percent difference made by a second bidder cost Kentucky taxpayers nearly $\$ 100$ million of the $\$ 593$ million spent on paving contracts during the 2005-07 period.

Table 1: Summary Statistics of All KYTC Projects in Kentucky, 2005-2007

\begin{tabular}{|c|c|c|c|c|c|c|}
\hline \multirow{3}{*}{$\begin{array}{l}\text { Number of } \\
\text { Bidders }\end{array}$} & \multicolumn{2}{|c|}{ Number of Projects } & \multicolumn{2}{|c|}{$\begin{array}{c}\text { Total Value of Projects } \\
\text { (\$ in millions) }\end{array}$} & \multicolumn{2}{|c|}{$\begin{array}{c}\text { Over or Under Engineer's } \\
\text { Estimate (\%) }\end{array}$} \\
\hline & Asphalt & All Other & Asphalt & All Other & Asphalt & All Other \\
\hline & Projects & Projects* & Projects & Projects* & Projects & Projects* \\
\hline 1 & 677 & 154 & 429.1 & 737.6 & 2.20 & 2.38 \\
\hline 2 & 284 & 223 & 120.3 & 800.8 & -13.62 & -6.02 \\
\hline 3 & 72 & 211 & 33.2 & 488.3 & -16.82 & -13.22 \\
\hline 4 & 24 & 153 & 8.7 & 174.4 & -16.87 & -16.02 \\
\hline 5 & 3 & 83 & 1.8 & 144.0 & -14.15 & -19.52 \\
\hline 6 & & 43 & & 49.8 & & -17.22 \\
\hline 7 & & 23 & & 44.0 & & -21.30 \\
\hline 8 & & 12 & & 17.1 & & -16.07 \\
\hline 9 & & 7 & & 4.6 & & -26.08 \\
\hline 12 & & 1 & & 0.7 & & -11.05 \\
\hline Grand Total & 1060 & 910 & 593.1 & $2,461.1$ & -3.81 & -10.39 \\
\hline
\end{tabular}

*These other projects include grade and drain, bridge, mowing, concrete, etc. Some of these projects have asphalt components as part of the project

At one level, the goal of this paper is to explore the nature of bidding in highway procurement auctions. At another level, we hope to add to economists' understanding of tacit collusion in oligopoly markets. The primary question is whether so many auctions attract only a single bidder because rival firms are coordinating their bids. We start by reviewing the history of bid rigging in the asphalt industry and methods used to detect collusion in auctions. We discuss how procedural mechanics of highway procurement auctions and economic aspects of asphalt 
paving create a bidding environment that facilitates coordination in the repeated bidding game that rival contractors engage in. We then determine feasible service areas for all asphalt contractors in Kentucky and analyze bidding behavior to see what factors influence both the decision to bid and how much to bid. We find that, in many parts of the state, county boundaries create a natural focal point for bidding that helps firms solve their repeated coordination game by refraining from bidding in rival firms' territories.

\section{Bid Rigging in the Asphalt Industry}

During the period of analysis in this paper, there is no evidence of overt collusion in Kentucky, nor is there any suspicion of illegal activity, even though the Kentucky Transportation Cabinet annually gathered highway contractors for a bid-letting meeting and sponsored a social function the night before. Since several principals and companies in the present empirical analysis were implicated in bid rigging and illegal collusion in Kentucky during the early 1980s, a brief overview of past overt collusion in highway procurement auctions is warranted. ${ }^{10}$

Antitrust enforcement changed its focus in the early 1980s, switching from large monopoly cases to price fixing and collusion. A pattern of highway bid rigging was uncovered in Tennessee and in other states. In Tennessee, contractors gathered in a Nashville hotel the night before bid lettings to determine who would be the winning (low) bidder. Other contractors would

\footnotetext{
${ }^{10}$ The owner of Mountain Enterprises, an asphalt paving company in eastern Kentucky, provided the following description of how the collusion worked:

It was agreed that Kentucky Virginia Stone would take both of the jobs available at that letting and the two jobs available at the next letting were then split up. So that Mountain Enterprises got one of the four, Kentucky Virginia Stone got three of the four, and that roughly split or equaled out the tonnages on those four jobs. These were the first four jobs which were made subject to the agreement between Kentucky Virginia Stone and Mountain Enterprises .... They would work out who was going to get which job and then information would be passed so that someone could either submit a complementary bid or not bid (Lawson, 1983, pp. 9-10).
} 
submit complementary (higher) bids, in return for payoffs from the winner or the promise of being the low bidder in a future auction (rotation of low bidders). ${ }^{11}$ By 1984 the federal investigation of highway bidding had expanded into 29 states, with 181 corporations and 189 individuals pleading guilty, 21 corporations and 25 individuals being convicted at trial, and 16 corporations and 22 individuals being acquitted. ${ }^{12}$ In all, there were over 600 highway bidrigging cases during the 1980 s. $^{13}$

Since the 1980s the Department of Justice has shifted its emphasis from the prosecution of bid rigging, in no small part because of a general belief that overt collusion occurs less frequently due to heavy prosecution during the 1980s and better methods, such as wiretaps, for detecting bid rigging. This is not to say, however, that highway procurement auctions are highly competitive. In an August 2005 meeting of the American Association of State Highway and Transportation Officials (AASHTO) Subcommittee on Construction, the committee identified single-bid contracts and decreasing competition as major concerns. According to a survey commissioned by AASHTO (2006), the average number of bidders per project declined from 4.24 in 2002 to 3.36 in 2005 . In Kentucky the average number of bidders declined from 2.94 in 2002 to 2.18 in $2005 .{ }^{14}$ As is evident in Table 1 , single-bid contracts are more prevalent in asphalt resurfacing projects than other highway construction or maintenance projects. These facts motivate our analysis. The question remains whether the high level of single-bid contracts represents an efficient equilibrium or is the result of tacit collusion.

\footnotetext{
${ }^{11}$ Sniffen (1982).

${ }^{12}$ Sniffen (1984)

${ }^{13}$ Ryan (2004).

14 Two major reasons cited by departments of transportation for the decline of bids were industry consolidation and increased work with the same number of contractors. Data from Kentucky, however, indicate that industry consolidation was not a problem: From 2005 to 2007 the average number of projects per firm was 10.4 in Kentucky, while the average from 1994 to 2007 was 11.2 projects per firm.
} 


\section{Detecting Collusion in Auctions}

Detecting collusion and cartels has long been a primary concern of industrial organization economists (e.g., Stigler, 1964). Both Porter (2005) and Harrington (2008) have suggested that economists are best positioned to play the role of detective-diagnosing either explicit or tacit cooperation among firms. Concomitant with increased focus on price fixing and bid rigging by federal antitrust investigators in the 1980s, economists began paying greater attention to, and worked to develop methods to identify, collusive behavior in auctions (e.g., Graham and Marshall, 1987; McAfee and McMillan, 1987). Isaac and Walker (1985) investigated bid rigging in sealed bid auctions and the effect of non-cooperating bidders in a laboratory experiment setting. Building on theoretical and empirical research on bid rigging in auctions, both Klemperer (2002) and Marshall and Marx (2009) discussed the importance of auction design in thwarting collusion. ${ }^{15}$

Highway procurement auctions have been a particular area of focus both because of readily available data and high susceptibility to collusion. Funderburk (1974) described an early use of economic analysis to identify the existence of a conspiracy among bidders for liquid asphalt contracts with the Oklahoma transportation department. Feinstein, Block, and Nold (1985) theoretically and empirically analyzed information asymmetries between highway construction cartels and the states that purchased their services. They found that cartels actively fed misinformation to the North Carolina transportation department to change the purchaser's (the state) expectation on what constituted a "good buy."16

\footnotetext{
${ }^{15}$ A thorough summary of this literature is contained in Hendricks, McAfee, and Williams (2015).

${ }^{16}$ Brannman and Klein (1992) also investigated highway construction bid rigging in North Carolina.
} 
Porter and Zona (1993) developed an econometric test to detect bid rigging in highway procurement auctions. They focused specifically on auctions where there were more than two bids and attempted to detect "phantom" bidding. A phantom bid is a one that looks competitive because multiple firms are bidding; however, the identities of the low and high bidders are determined by the participating firms before the bids are submitted. This overt collusion gives the appearance that numerous firms are competing for a project, but in reality the winner of the bid is predetermined.

Bajari and Ye (2003) developed econometric tools to detect collusive behavior and empirically analyzed data on highway seal-coating contracts in Minnesota, North Dakota, and South Dakota. They incorporated cost asymmetries among bidders in their model. Cost asymmetries arise due to firms' locations, capacity constraints, and knowledge of local rules and regulations. They tested for conditional independence to determine whether bids were independent and for exchangeability to determine whether costs and not just the presence of competitors drove bid levels. Lastly, they took into account industry experts' opinions about realistic distribution of markups to determine whether the market was competitive or collusive.

The literature on collusion in auctions extends into other sectors including electricity, timber, the electromagnetic spectrum, public works, and the dairy industry. Focusing on the electricity industry in England and Wales, Fabra (2003) modeled tacit collusion in uniform-price and discriminatory auctions in a repeated setting that allowed firms to sustain collusive behavior. Baldwin, Marshall, and Richard (1997) controlled for demand conditions and found that a collusive model outperforms the "standard" model of non-cooperative behavior in Pacific Northwest timber auctions. Price (2008) extended Bajari and Ye's (2003) model into timber auctions in British Columbia and incorporated the spatial distribution of bidders to detect 
collusion. Cramton and Schwartz (2000) investigated the FCC's simultaneous ascending auction design and found that it facilitated tacit collusion in spectrum auctions around the country. Lee and Hahn (2002) and Ishii (2009) analyzed bidding on public works projects in Korea and Japan, finding evidence of collusive behavior. Research has also focused on collusion in school milk procurement auctions during the 1980s and 1990s. Pesendorfer (2000), Porter and Zona (1999), Lee (1999), Lanzillotti (1996), and Scott (2000) analyzed bid rigging in Florida and Tennessee, Ohio, Texas, and Kentucky respectively.

\section{Highway Procurement Auctions}

Certain elements of highway procurement auctions, as well as political and geographical factors, create a market environment that facilitates collusive outcomes. Since the approach taken by the Kentucky Transportation Cabinet (KYTC) to procure construction and maintenance work is generally representative, we will use it as an example. There are many different types of projects to be carried out, ranging from constructing new roads, resurfacing existing roads, trimming trees and mowing grass, maintaining and replacing bridges, building fences, and painting lines. Of particular importance is that when certain funds are used, KYTC is required to separate funds by county, and so it usually separates projects by county. ${ }^{17}$

For reasons discussed below, our primary interest is asphalt paving projects. Major asphalt jobs originate from a comprehensive, full planning process, are attached to a Six-Year Plan and State Transportation Improvement Plan, and are approved by the state legislature. Minor, routine asphalt resurfacing projects are typically initiated within KYTC and do not need

\footnotetext{
${ }^{17}$ A KYTC transportation official stated that for certain types of projects designated "rural secondary," the money must go to the specific counties.
} 
to be approved by the legislature. The vast majority of the projects analyzed for this paper are minor resurfacing projects. ${ }^{18}$

In Kentucky, projects are let on a monthly schedule, but this can vary from state to state. In most states, each project is advertised for a certain period of time, bid proposals and plans are available for purchase, and then bids are submitted. Most states require that contractors working for them must be prequalified and also require that bid proposal and/or project plans must be purchased. ${ }^{19}$ In Kentucky a project must be advertised 7-21 days before the project is let. Firms must purchase a bid proposal to be eligible to bid on a project. The bid proposal costs $\$ 10$ and the names of firms that purchase bid proposals are publicly available the Friday before bids are due to KYTC headquarters.

All firms in Kentucky must be pre-qualified by the transportation cabinet, and the list of pre-qualified firms is publicly available. Care is taken by KYTC that a contractor does not take on too much work, and officials hold meetings with all potential contractors on projects scheduled for the upcoming year to determine the letting schedule. Projects are moved around on the calendar in order to accommodate potential contractors.

Sealed bids are opened and read aloud once a month at the Kentucky Transportation Cabinet. KYTC then analyzes the bids for 10 days before awarding a contract. The bids are analyzed to see if the bid is unbalanced, front-loaded, or if there is any indication of collusion. ${ }^{20}$ The transportation cabinet looks at the overall total of each bid and compares it to the state highway engineer's estimate. In some states the engineer's estimate is available before the day of

\footnotetext{
${ }^{18}$ Kentucky Transportation Cabinet (2004).

${ }^{19}$ Anderson and Blaschke (2004).

${ }^{20}$ Kentucky and other states use the AASHTO Transport System, a program used to detect collusion. It can compare bids to the engineer's estimate and the other contractors who bid It can also create reports on past bidding behavior, market prices, and price differences according to various parameters such as geography.
} 
bidding, while in other states like Kentucky it is not available until after bids are opened. An informal rule in Kentucky is that if a bid is 7 percent over the engineer's estimate it should be rejected, however, this rule is infrequently followed. If KYTC judges all aspects of the bid to be reasonable then the project is awarded, even if there is only one bidder.

\section{Economic Aspects of Asphalt Paving}

We focus on asphalt paving and do not consider other types of projects such as grade and drain, bridge work, mowing, etc. The important element of the asphalt paving process is the time constraint, which limits how far away from its plant a particular firm can bid-the firm's feasible service area. Projects farther from a plant result in higher costs to the firm because asphalt is heavy and hence costly to transport. As a result, the geographic scope of the market for asphalt projects is much smaller than geographic market scope for road and bridge construction, mowing, and other highway maintenance projects.

Other factors relevant to asphalt production and paving are high start-up costs (some of which take the form of environmental permits), economies of scale at the plant level, potential problems of obtaining aggregate (sand and gravel), and the fact that hot-mix asphalt must be compacted while it is very hot. These factors greatly influence the competitive landscape faced by asphalt contractors bidding in procurement auctions.

The process of paving a road begins with the extraction of rock (aggregate) from a quarry and the distillation of asphalt cement or bitumen from crude oil. The cost of producing asphalt varies as the prices of aggregate and asphalt cement vary. These two components are combined at high temperatures at an asphalt plant when asphalt cement is in liquid form. The resulting hotmix asphalt is dispensed into trucks and driven to the project site. Care has to be taken to not let 
the mixture cool too much before compaction. It must be laid and compacted before the temperature of the mixture falls below $85^{\circ} \mathrm{C}\left(185^{\circ} \mathrm{F}\right)$. Below this temperature the asphalt starts to crack and will not set properly.

Transportation of hot-mix asphalt from plant to project site is another significant cost. The trucks are often insulated and the bed is usually covered with a tarp. A general guideline is that hot-mix asphalt has two to three hours in an insulated truck before it becomes too cool. ${ }^{21}$ However, an official of the Kentucky Transportation Cabinet stated that between 45 and 60 minutes from when the hot-mix asphalt is dispensed to when it is compacted is a more realistic time frame. This time frame is critical in determining the extent of a firm's feasible service area. The calculation of feasible service areas is important in the analysis of tacit collusion, and is discussed further in the Data section.

\section{Coordination of Bidding in a Repeated Multistage Game}

There is considerable variation in the bidding environment faced by asphalt paving firms in Kentucky. Northern Kentucky and the greater Louisville area are large urban markets and can support multiple asphalt companies. In addition to dense public road networks, there is considerable commercial demand for asphalt paving and so the market environment is very competitive with multiple firms. In many other parts of the state, demand for asphalt paving is sufficient to support geographically dispersed oligopolists whose feasible service territories only partially overlap. ${ }^{22}$ It is in this type of market environment that strategic interactions among

\footnotetext{
${ }^{21}$ AASHTO, (2000).

${ }^{22}$ In eastern Kentucky the market is much thinner, because of sparse population and negligible commercial paving demand. Since the 1980s, the region has been served by one multi-plant firm, which operates each of its plants on a rotating basis with transient plant and paving crews. The market environment resembles natural monopoly, in that there only seems to be enough business to support one efficient-sized firm.
} 
firms are important. The prevalence of these oligopoly/duopoly markets is demonstrated in

Figure 1, which illustrates every asphalt plant in Kentucky approved to bid on state contracts during the sample period. ${ }^{23}$ As can be seen, 31.7 percent of the 120 counties in Kentucky did not have an asphalt plant located within the county, 60.0 percent of counties had one plant, and 8.4 percent had more than one.

Bidding in a competitive environment has been thoroughly discussed by other authors. We have little to add, except to use competitive areas as a benchmark for comparison. Bidding under natural monopoly is straightforward: How high above the state engineer's estimate can a firm bid and not be rejected by KYTC ${ }^{24}$ Oligopoly bidding gets interesting: If firms are able to coordinate their bidding behavior, then how do they determine which firm should win a particular auction, how rotate winners, and how the designated losers should bid, if at all?

This bidding scenario thus has elements of a repeated multistage game, where in the first stage firms decide whether to enter a particular auction, and in the second stage those who enter decide what price to bid. Collusive coordination requires either side payments or rotation of winners. Side payments are by definition overt and illegal. Complementary bids and refraining from bidding are illegal if firms directly and overtly agree to pursue such strategies. Refraining from bidding generally is not illegal if a firm unilaterally decides that such a strategy is in its own best

\footnotetext{
${ }^{23}$ Figure 1 is taken from the Plantmix Asphalt Industry of Kentucky web site.

${ }^{24}$ There are numerous examples of single-bidder paving companies playing "chicken" with KYTC, having an initial bid rejected and the project being put up for rebid. On several occasions there have been three and four rounds of rejected bids and rebidding. The usual outcome is that KYTC ultimately blinks when there is no viable alternative supplier. Barrus (2011) discusses several examples of such interactions.
} 
Figure 1: Asphalt Plant Locations in Kentucky

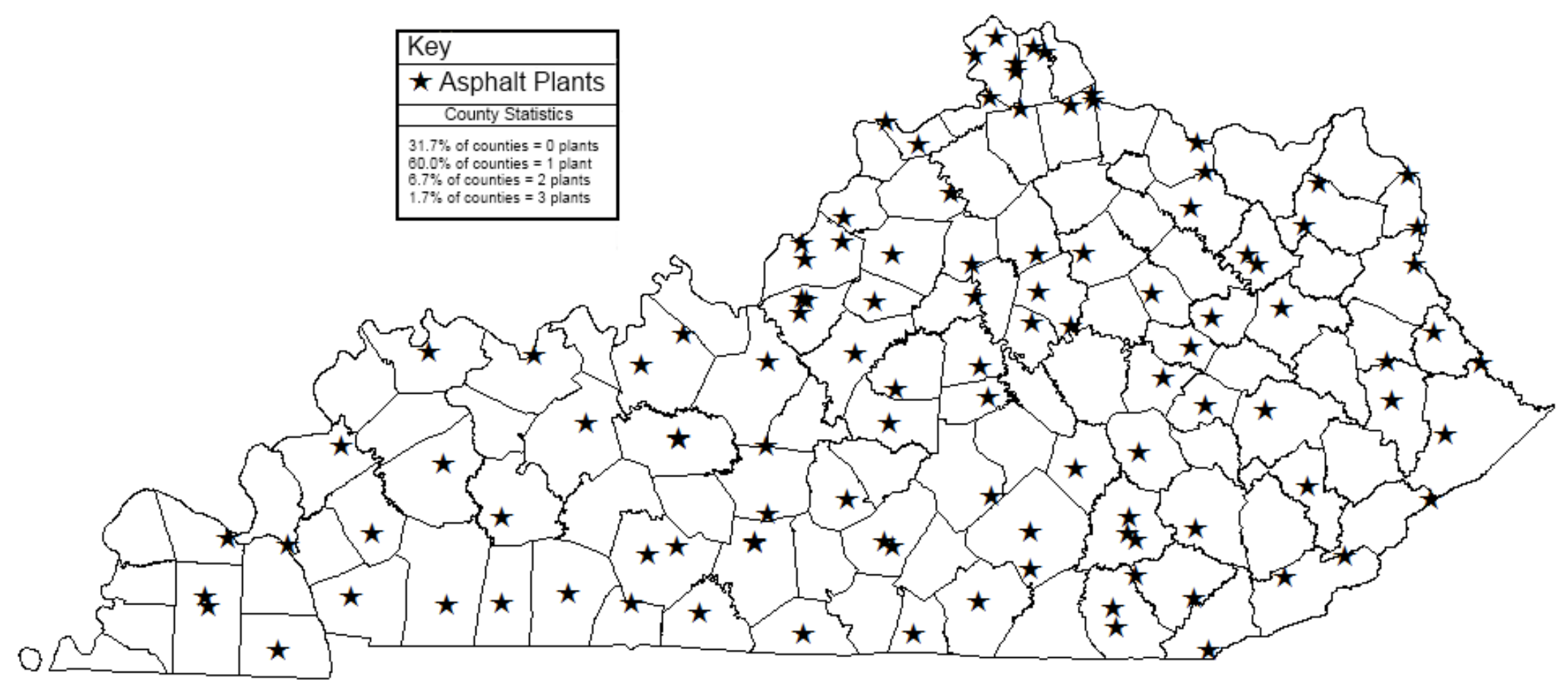


economic interest. ${ }^{25}$ The global profit maximum for all players requires that the low-cost firm for each project wins the auction. If each player wins often enough to consider the outcome equitable, then the only problem is devising a bid rotation scheme in which the low-cost firm is always the designated winner. With multiple firms and multiple projects, overt communication may be required to reach this outcome. ${ }^{26}$ When the number of potential bidders is small, however, firms may recognize their mutual interest in suppressing competition without direct communication. ${ }^{27}$ The existence of a natural focal point may obviate the need for overt collusion. If procurement auctions are configured to create an easy way for firms to allocate contracts and refrain from bidding against one another without openly communicating, then tacit collusion may accomplish the same outcome as would occur under an illegal cartel. ${ }^{28}$

The problem can be modeled as follows: Consider two firms, $\mathrm{X}$ and $\mathrm{Y}$, that produce a product that is costly to deliver and are located at some distance from each other. They must decide whether to bid on a project that is located distances $d_{x}$ from $X$ and $d_{y}$ from $Y$. Each incurs production and transportation costs of $\mathrm{C}_{\mathrm{x}}$ and $\mathrm{C}_{\mathrm{y}}$, respectively, if they win the bid and carry out the project. There is a random element of $\varepsilon$ associated with each firm's costs, so that neither

\footnotetext{
${ }^{25}$ See Werden's (2004) discussion of the legal status and treatment of tacit vs. overt collusion, especially pp. 73459. Yao and DeSanti (1993) also discuss the legal quandaries of prosecuting tacit collusion. Page (2016) provides an in-depth analysis of what constitutes an illegal agreement.

${ }^{26}$ This is precisely the scenario studied by Porter and Zona (1993), whereby highway contractors on Long Island devised a bid rotation scheme with designated losers submitting complementary bids. See also Conley and Decarolis's (2016) analysis of bidding cartels in Italy.

${ }^{27}$ As Fraas and Greer (1977, pp. 29-31) point out, the necessity of a formal collusive agreement increases as structural conditions become more adverse to tacit cooperation. With two firms selling a standardized product, overt collusion may be immanently possible but not really needed. Their empirical analysis of 606 explicit price fixing cases from 1910 to 1972 confirms this conjecture.

${ }^{28}$ Green, Marshall, and Marx (2015) argue that most market environments are sufficiently complex that collusion will be unsuccessful in the absence of explicit communication. But in a market that is so simple and transparent that "there is a unique candidate for the optimal collusive agreement," i.e., a focal point, then tacit collusion may suffice. Lewis (2015) analyzes how pricing focal points facilitate tacit collusion in gasoline retailing.
} 
knows its own or its rival's costs with certainty ex ante. The following diagram illustrates this scenario:

Firm X

\section{Project \#1}

Firm Y

$\mathbf{d x}_{\mathbf{x}}$

$\mathbf{d y}_{\mathbf{y}}$

There are three possibilities: (1) $d_{x}<d_{y}$ such that $\left|C_{x}-C_{y}\right|>\varepsilon$, i.e., firm $X$ is considerably closer and so has a clear cost advantage; (2) $d_{x}>d_{y}$ such that $\left|C_{x}-C_{y}\right|>\varepsilon$, i.e., firm Y is considerably closer and so has a clear cost advantage; and (3) $d_{x} \approx d_{y}$ such that $\left|C_{x}-C_{y}\right|<\varepsilon$, i.e., firms $X$ and $\mathrm{Y}$ are roughly equidistant and so neither firm has a clear cost advantage.

Let us first analyze the case where firm $\mathrm{X}$ has a clear cost advantage, i.e., condition (1) above holds. Each firm must decide whether to bid and, if so, how much to bid. Firm X will clearly participate in the auction, so we focus on firm Y's participation and pricing decisions. As illustrated below, these can be represented as a two-stage sequential-move game, in which the first stage represents firm Y's decision to enter or stay out of the auction. In the second stage, if firm $\mathrm{Y}$ decides not to enter, then firm $\mathrm{X}$ is the only bidder. But if firm $\mathrm{Y}$ enters and submits a bid, the two firms play a simultaneous-move pricing game: ${ }^{29}$

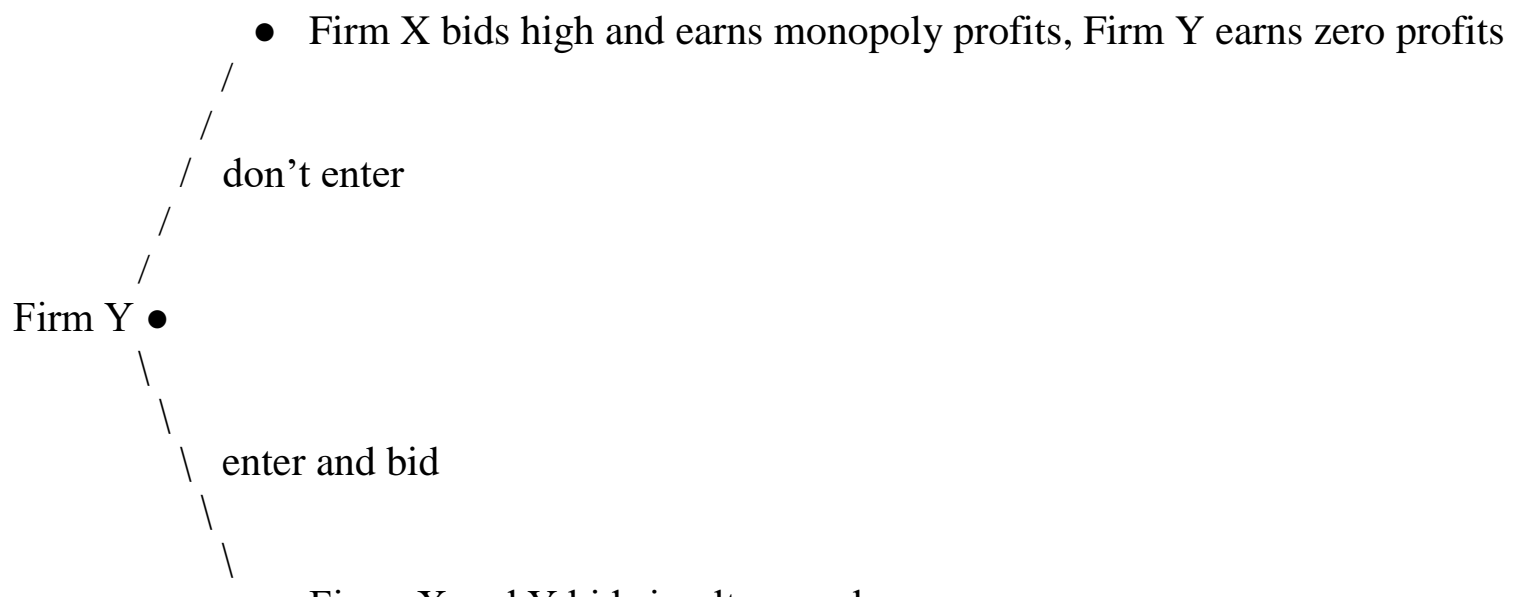

- Firms $\mathrm{X}$ and $\mathrm{Y}$ bid simultaneously:

${ }^{29}$ This particular configuration of a multistage entry game comes from Dixit and Skeath (2004), pp. 155-161. 
Firm Y

\begin{tabular}{|c|c|c|c|}
\hline \multirow{4}{*}{ Firm X } & $\mathbf{P}_{\mathbf{c}}$ & $\mathbf{P}_{\mathbf{m}}$ \\
\cline { 2 - 4 } & $\mathbf{P}_{\mathbf{c}}$ & $\pi_{\mathbf{c}^{\mathbf{x}}},-\mathbf{c}_{b i d}$ & $\pi_{\mathbf{c}^{\mathbf{x}},-\mathbf{c}_{b i d}}$ \\
\cline { 2 - 4 } & $\mathbf{P}_{\mathbf{m}}$ & $-\mathbf{c}_{b i d}, \pi_{\mathbf{c}^{\mathbf{y}}}$ & $\pi_{\mathbf{m}^{\mathbf{x}}},-\mathbf{c}_{b i d}$ \\
\hline
\end{tabular}

In the pricing game payoff matrix, we restrict bid options for each firm to bidding competitively $\left(\mathrm{P}_{\mathrm{c}}\right)$ or bidding monopolistically $\left(\mathrm{P}_{\mathrm{m}}\right)$. Since firm $\mathrm{X}$ has a clear cost advantage, it will always win if both firms bid competitively. ${ }^{30}$ Without digressing into a deeper discussion of economic profits, let us assume that winning the auction when bidding is noncompetitive yields more profit $\left(\pi_{\mathrm{m}}\right)$ than winning when bidding is competitive $\left(\pi_{\mathrm{c}}\right)$ and that either is better than not winning the auction ( $\pi=-\mathrm{c}_{\text {bid, }}$, where $\mathrm{c}_{\text {bid }}$ represents the cost of preparing and submitting a bid).

The Nash equilibrium to the second-stage pricing game is that both firms bid competitively and firm $\mathrm{X}$ has the lower bid due to its locational cost advantage. It then earns competitive profits on the project while firm Y incurs the cost of submitting a bid and has nothing to show for it. In the first stage, looking ahead to the outcome of this pricing game and reasoning backward, firm $\mathrm{Y}$ will choose not to enter the auction and submit a bid. Because of symmetry, if firm Y has a significant locational advantage the outcome would be reversed and firm $X$ would choose not to enter and submit a bid.

The third possibility is that the project is roughly equidistant from each firm, so that neither has a clear cost advantage. If both firms enter the auction and bid, the payoff matrix for this game is the classic Prisoner's Dilemma. If the game is played repeatedly and firms are unable to cooperate, then each firm will bid competitively, and sometimes firm X will win and

\footnotetext{
${ }^{30}$ Let us assert that firm $\mathrm{X}$ also wins if both firms bid noncompetitively, since firm X's bid will be lower than firm Y's if both use the same relative markup.
} 
sometimes firm Y will win. Indeed, this seems to be the outcome for procurement auctions conducted in the northern Kentucky and greater Louisville markets where there are multiple bidders. On the other hand, if coordination is achieved, either overtly or tacitly, the collusive duopoly pricing outcome can be sustained.

In actuality, many asphalt paving firms in Kentucky play this game repeatedly against an identifiable rival, with KYTC putting projects up for bid in various locations at regular intervals. If roughly half the projects let for bids were clearly closer to firm $\mathrm{X}$ and the other half were clearly closer to firm Y, it would be unsurprising if the two firms used distance as a focal point for cooperation and either refrained from bidding or bid noncompetitively, with the more distant firm's noncompetitive bid being higher than the closer firm's noncompetitive bid. ${ }^{31}$

Projects roughly equidistant from both firms create a problem for such coordination, however, and so relying solely on distance as a focal point for cooperation may give rise to outbreaks of competitive bidding (price wars) or temptations to overtly collude. Fortunately for asphalt oligopolists (and unfortunately for Kentucky taxpayers), KYTC refines this focal point by assigning asphalt projects strictly according to county boundaries. In adjacent counties where there is only one company with an asphalt plant in each county, the natural focal point outcome is hard to miss.

The different possible bidding scenarios can be seen in Figure 2. It illustrates two firms (X and Y), four counties (A-D), and four projects (1-4). Project 1 is located in county A where firm $\mathrm{X}$ has the only asphalt plant. Project 2 is located in adjacent county B where rival firm Y

\footnotetext{
${ }^{31}$ This is precisely the collusive outcome achieved by Oklahoma asphalt companies during the 1960s as described in Funderburk (1974).
} 
has the only asphalt plant. Project 3 is located in county $\mathrm{C}$ where both firms $\mathrm{X}$ and $\mathrm{Y}$ have asphalt plants. Project 4 is located in county D where neither firm X nor $\mathrm{Y}$ has an asphalt plant.

\section{Figure 2: County Boundaries and Bid Coordination}

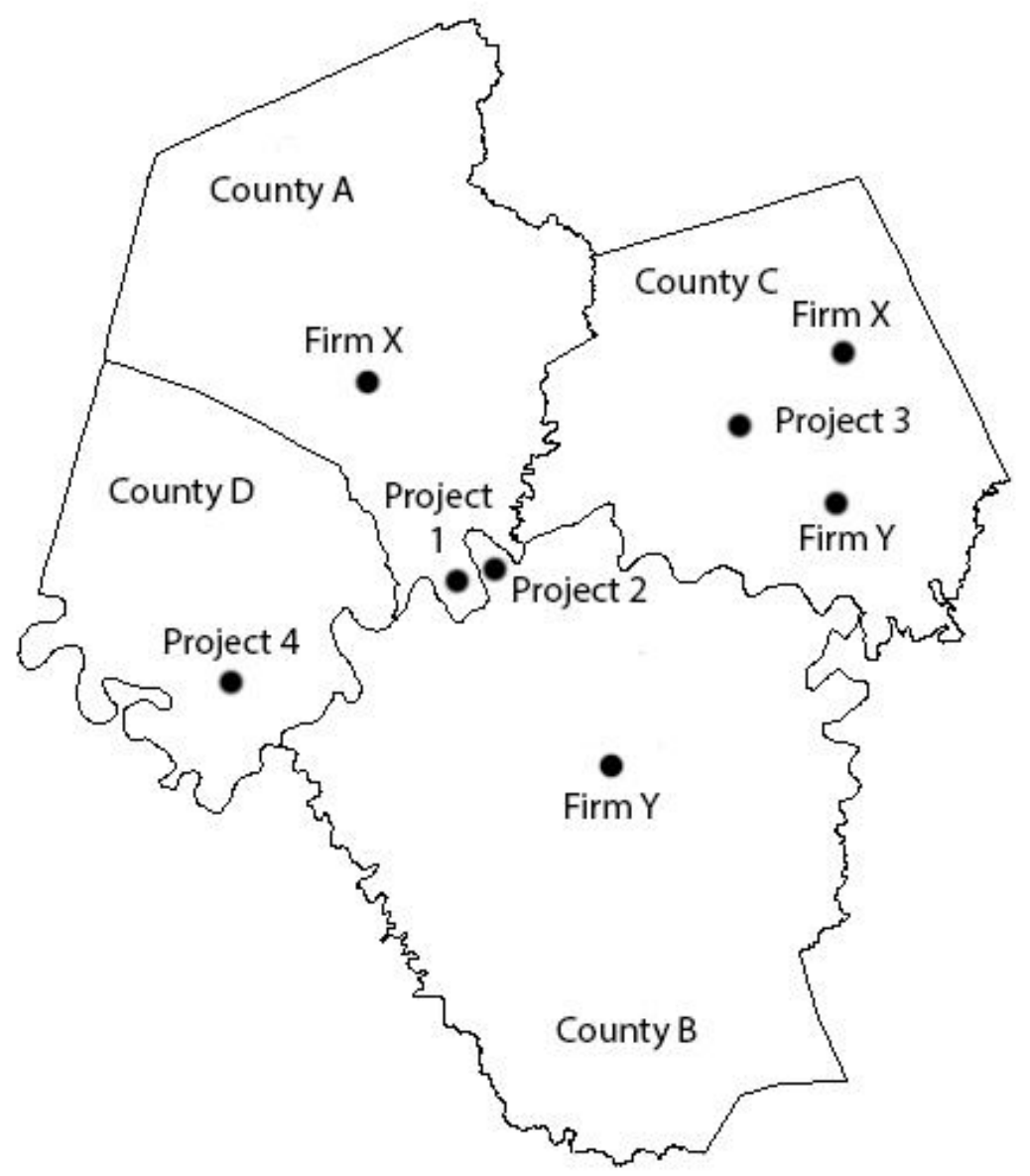

Projects 1 and 2 are roughly equidistant from both firm X and firm Y. In a "flat" world, each firm would have similar costs of carrying out each of the two projects. With no focal point for cooperation, it is not clear how the two firms might reach a noncompetitive bidding equilibrium without overt communication. If projects are delineated by county lines, however, and each firm has the only asphalt plant in its own county, then the natural focal point for cooperation is for firm $\mathrm{X}$ to carry out project 1 and firm $\mathrm{Y}$ to carry out project 2, both at 
noncompetitively high bids. By requiring advance purchase of official plans and publicly identifying firms that have purchased plans prior to bid submission deadlines, KYTC bidding rules make it easy for firms to charge super-competitive prices. Firm $\mathrm{Y}$ can signal firm $\mathrm{X}$ that it does not intend to enter and bid on project 1 by not purchasing an official set of plans, leaving firm $\mathrm{X}$ as the sole bidder (and vice versa for project 2).

For projects 3 and 4, there are no natural focal points for cooperation. Project 3 is located in county $\mathrm{C}$, where rival firms $\mathrm{X}$ and $\mathrm{Y}$ both have asphalt plants. Project 3 is roughly equidistant from both firms. With no clear focal point to guide the firms' cooperative instincts, competitive bidding is likely to occur absent overt communication between the firms. Project 4 is located in county D, which is adjacent to both Counties A and B and has no asphalt plant located within its boundaries. Project 4 is also roughly equidistant from the asphalt plants of both $\mathrm{X}$ and Y. Again there is no clear focal point for cooperation, and without overt collusion the bidding is likely to be competitive.

This suggests a strategy for identifying whether firms use county boundaries as focal points for coordinating bids. In a flat world with no political boundaries, firms will consider their own costs of carrying out a particular project and size up the likely bids of other potential suppliers when formulating their bid. In a thick market where multiple firms have overlapping viable service territories, we would expect competitive pricing to prevail, with closer firms exploiting any slight cost advantage and submitting lower bids. In a thin market where perhaps only two firms can viably serve a proposed project, whether to participate and how much to bid will also be affected by distance — distance from own plant to the project and distance advantage (or disadvantage) relative to the rival. Distance variables are thus predicted to significantly affect 
both the participation decision and the pricing decision in thick markets and in thin markets, and arbitrary lines on a map should have no explanatory power. ${ }^{32}$

If, on the other hand, firms in thin markets bid repeatedly against one another in the same geographic space, coordination may arise. As discussed earlier, coordination on projects where one or the other firm has a clear distance-based cost advantage is easy - the more distant firm opts not to enter and bid, and the nearer firm as the only bidder is able to set a monopoly price. But when neither firm has a clear cost advantage, coordination becomes a challenge. It is in this setting that county boundaries may serve as a focal point, with each firm bidding within the county where its plant is located. If such bid coordination is occurring, then inclusion of variables identifying county type as in Figure 2 will have explanatory power above and beyond the distance measures.

\section{Data}

The purpose of our empirical analysis is to see if firms are coordinating bids. The data used are publicly available and were obtained from the Kentucky Transportation Cabinet for the years 2005-07. Information on contracts awarded, which firms purchased bid proposals, which firms actually bid on each project, the amount of each bid, the winning firm, and the engineer's estimate were obtained from the KYTC Construction Procurement website. These detailed data

\footnotetext{
${ }^{32}$ It is reasonable to ask whether county borders are arbitrary lines on a map or instead proxy for unmeasured aspects of the geography that might keep potential bidders out. In a larger state with fewer counties, this concern might be more worrisome. For historical reasons (https://en.wikipedia.org/wiki/List_of_counties_in_Kentucky), Kentucky has more counties (120) than all other states except Georgia (159) and Texas (254). The average area of counties in Kentucky (329 square miles) is smaller than all other states except Virginia (295 square miles) and Rhode Island (207 square miles). Many of the projects that attract only a single bidder actually consist of a stretch of road that passes through two counties and is split into two separate projects for bid-letting purposes, with the split occurring at the county line. Finally, the mapping algorithm for viable service territories utilizes primary and secondary roads that are minimally rated to handle dual rear-axle dump trucks.
} 
were only available after 2005 on the KYTC website. Upon request, the Kentucky

Transportation Cabinet supplied project location (latitude and longitude for the mid-point of each project) information for the projects in Kentucky from 1996-2009. These data also included information on the type of work, including a short description of what the project entailed along with information about the road, location, and number of bids. This was supplemented with another KYTC data set that contained all awarded contracts in Kentucky from 1994-2010.

Information about plant locations came from various sources, including the Plantmix Asphalt Industry of Kentucky (PAIKY) website, the Division of Materials within the Transportation Cabinet, air quality permits obtained from the Division of Air Quality within the Environmental and Public Protection Cabinet, and individual firm websites. For a few firms, the locations of the asphalt plants were confirmed by telephone. A total of 1,985 projects were let and awarded from 2005 to 2007 . We identified asphalt projects using the KYTC label for each project that briefly summarized the scope of the project. In order to qualify as an asphalt project, the job could not have any other element except asphalt surfacing, resurfacing, rehabilitation, or patching. Asphalt projects that had grade and drain, bridge, or guardrail components were not included in the "asphalt" projects for this analysis, leaving us with 1,060 projects for analysis. ${ }^{33}$ These projects accounted for around $\$ 600$ million in expenditures by the Kentucky Transportation Cabinet.

\footnotetext{
${ }^{33}$ Projects with construction components attract a different (and partially overlapping) set of bidders, because the geographic scope of the market for these sorts of projects can be considerably larger than simple asphalt projects.
} 


\section{Firms and Counties}

During the sample period 31 major firms bid on asphalt paving projects in Kentucky. ${ }^{34}$ The 31 Kentucky firms have a total of 113 asphalt plants in the 120 Kentucky counties for an average of 0.94 plants per county. Figure 1 illustrates the location of each asphalt plant in Kentucky. Table 2 contains the names of the 31 firms, the number of asphalt plants each firm operates, the number of asphalt projects they bid on in Kentucky, the percentage of bids in which the firm was the single bidder, the number of contracts the firm won, and the value of the contracted projects. Considerable variation exists across firms. In the far western corner of Kentucky, H\&G Construction bid on 77 projects even though it only has one asphalt plant. It only won 14 of those projects; it was never the only bidder, always facing competition from Jim Smith Contracting and Murray Paving. Two central Kentucky firms, ATS Construction and Nally \& Gibson Georgetown, were sole bidders 100 percent of the time and hence won all of the projects they bid on.

\footnotetext{
${ }^{34}$ There were three additional Kentucky firms that showed up once or twice in the bid data, and four Indiana paving companies that were approved for state contract work and bid into Kentucky. One of the Indiana firms, Gohman Asphalt, is a frequent bidder in the Louisville market. We include the Kentucky bids of these out-of-state firms in our empirical analysis.
} 
Table 2. Firm bidding and the value of winning contracts for asphalt paving companies in Kentucky

\begin{tabular}{|c|c|c|c|c|c|}
\hline \multirow[b]{2}{*}{ Firms } & \multirow[b]{2}{*}{$\begin{array}{c}\text { Number of } \\
\text { Plants }\end{array}$} & \multicolumn{2}{|c|}{ Asphalt Paving Projects Bid on } & \multicolumn{2}{|c|}{ Asphalt Paving Contracts Won } \\
\hline & & $\begin{array}{c}\text { Number of } \\
\text { Bids }\end{array}$ & $\begin{array}{l}\text { Firm only bidder } \\
\text { on project (\%) }\end{array}$ & $\begin{array}{l}\text { Number of } \\
\text { Project Won }\end{array}$ & $\begin{array}{l}\text { Contracted Value of } \\
\text { Winning Projects (\$) }\end{array}$ \\
\hline THE ALLEN COMPANY INC & 3 & 54 & 50 & 49 & $15,308,473.15$ \\
\hline ATS CONSTRUCTION & 2 & 21 & 100 & 21 & $39,934,777.30$ \\
\hline BARRETT PAVING MATERIALS INC & 3 & 63 & 0 & 16 & $4,376,192.58$ \\
\hline BLACKTOP INDUSTRIES \& EQUIPMENT COMPANY & 1 & 11 & 0 & 2 & $528,974.50$ \\
\hline BLUEGRASS CONTRACTING CORPORATION & 1 & 31 & 0 & 8 & $2,227,065.31$ \\
\hline COMMERCIAL PAVERS INC & 3 & 44 & 0 & 24 & $18,353,377.60$ \\
\hline EATON ASPHALT PAVING CO INC & 5 & 99 & 3 & 43 & $12,210,883.50$ \\
\hline ELMO GREER \& SONS LLC & 10 & 69 & 55 & 66 & $34,306,098.30$ \\
\hline FLYNN BROTHERS CONTRACTING INC & 2 & 28 & 0 & 6 & 2,987,221.00 \\
\hline GADDIE-SHAMROCK LLC & 3 & 28 & 82 & 28 & $26,117,688.71$ \\
\hline GLASS PAVING INC & 2 & 20 & 70 & 16 & $10,558,645.85$ \\
\hline H \& G CONSTRUCTION COMPANY INC & 1 & 77 & 0 & 14 & $6,106,025.76$ \\
\hline H G MAYS CORPORATION & 3 & 38 & 45 & 32 & $16,388,222.00$ \\
\hline HINKLE CONTRACTING CORPORATION & 11 & 107 & 92 & 103 & $51,571,836.47$ \\
\hline JIM SMITH CONTRACTING COMPANY LLC & 3 & 86 & 14 & 72 & $29,068,199.65$ \\
\hline KAY \& KAY CONTRACTING LLC & 1 & 33 & 0 & 3 & $719,879.00$ \\
\hline LEXINGTON QUARRY COMPANY & 1 & 17 & 76 & 14 & $7,117,499.10$ \\
\hline LINCOLN COUNTY READY MIX INC \& & 1 & 28 & 0 & 5 & $2,226,384.48$ \\
\hline MAGO CONSTRUCTION COMPANY LLC & 12 & 101 & 47 & 88 & $38,670,973.43$ \\
\hline MOUNTAIN ENTERPRISES INC & 13 & 150 & 87 & 144 & $77,543,544.78$ \\
\hline MURRAY PAVING & 1 & 4 & 25 & 4 & $1,765,535.60$ \\
\hline NALLY \& GIBSON GEORGETOWN LLC D/B/A & 1 & 11 & 100 & 11 & $4,804,703.60$ \\
\hline NALLY \& HAYDON SURFACING LLC & 3 & 30 & 97 & 30 & $12,967,285.12$ \\
\hline OHIO VALLEY ASPHALT LLC & 3 & 33 & 39 & 27 & $7,344,865.32$ \\
\hline QUALIFIED PAVING LLC & 1 & 17 & 0 & 10 & $7,281,674.44$ \\
\hline ROAD BUILDERS \& PARKWAY CONSTRUCTION LLC & 2 & 38 & 76 & 33 & $24,192,496.38$ \\
\hline ROGERS GROUP INC & 5 & 53 & 74 & 50 & $37,252,115.20$ \\
\hline SCOTTY'S CONTRACTING AND STONE LLC & 12 & 118 & 61 & 96 & $69,271,902.25$ \\
\hline SHELBYVILLE ASPHALT COMPANY LLC & 1 & 6 & 17 & 3 & $692,378.10$ \\
\hline THE WALKER COMPANY OF KENTUCKY INC & 2 & 22 & 86 & 21 & $7,110,045.55$ \\
\hline YAGER MATERIALS LLC & 1 & 28 & 68 & 21 & $24,133,747.90$ \\
\hline
\end{tabular}

\section{Service Areas}

Political boundaries such as county boundaries and highway district boundaries do not

necessarily align with geographic economic markets. In asphalt paving, the feasible service

territory is the area where a firm can economically service any asphalt project (i.e. where the

firm can reasonably complete an asphalt paving job without the hot-mix asphalt cooling below

the temperature threshold). When looking at the distance from a firm's plants to projects it bid

on, there were no instances in the entire sample in which a firm bid on a project more than 60 
miles from its plant. The service area limit for every firm was thus set at 60 driving miles from each firm's asphalt plant. ${ }^{35}$

All mapping analysis was done in the ArcGIS ArcMap program using the Network Analyst function. We were able to determine and calculate the service areas and driving distances from asphalt plant to project. The software also mapped out these 60 -mile service areas. As an example, Figure 3 shows H\&G Construction's service area in western Kentucky and the projects on which it either did or did not bid in its service area. The different 10-mile bands indicate distance from H\&G's asphalt plant in Graves County. Visual inspection indicates the apparent importance of distance in the firm's bid decisions. In Livingston County, H\&G bid on a project almost 60 miles away from its plant.

\footnotetext{
${ }^{35} \mathrm{We}$ also tried 50-mile and 40-mile specifications of each firm's service area in the empirical work, with only very minor effects on coefficient magnitudes and significance.
} 
Figure 3: Service area - H\&G Construction in Western Kentucky

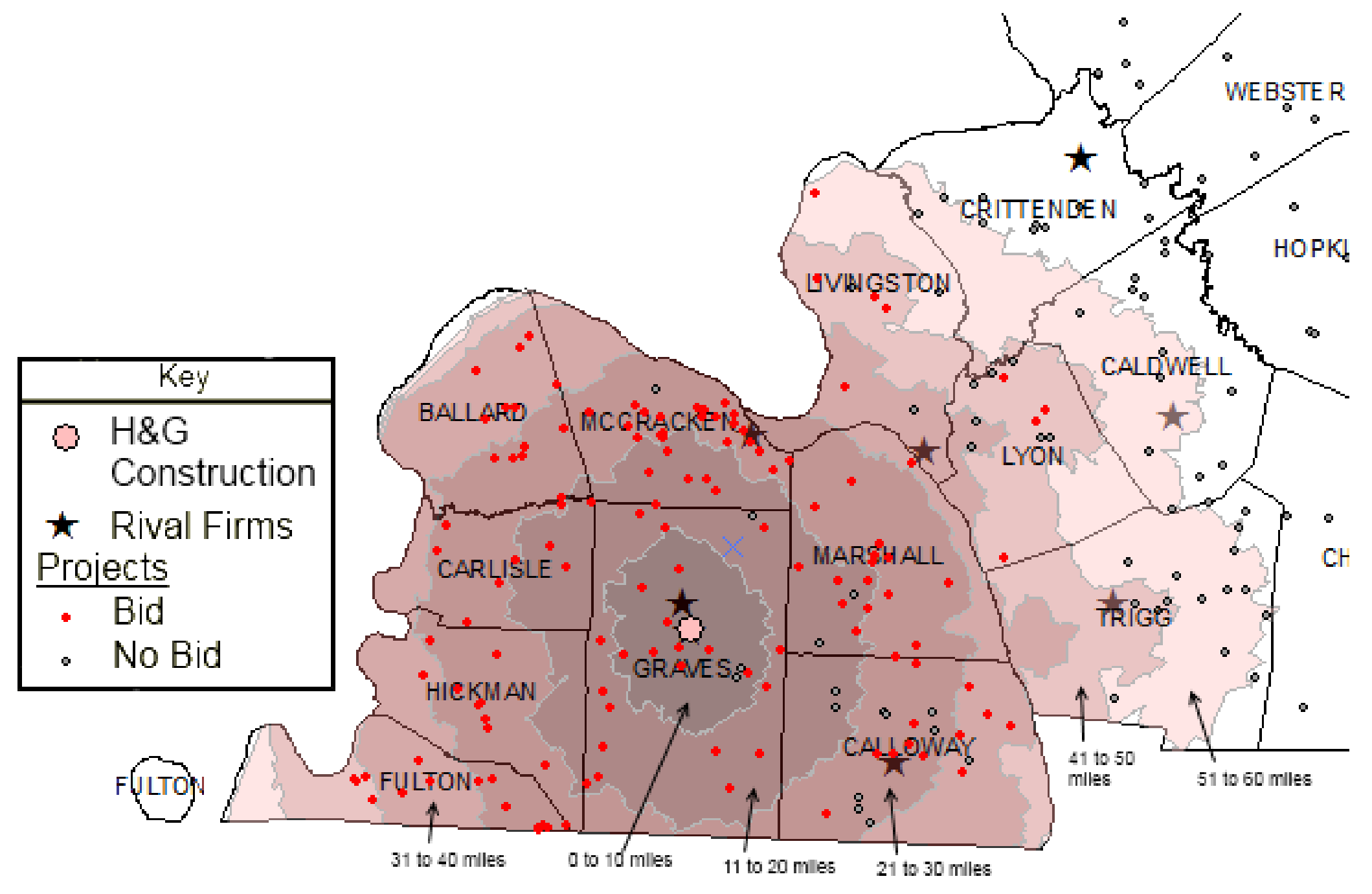




\section{Analyzing Bidding Behavior and Identifying Tacit Collusion}

Our goal is to investigate whether firms use county boundaries as focal points for tacit collusion. To accomplish that, we analyze both the participation decision and the pricing decision for the 31 firms bidding on asphalt projects in Kentucky. Previous authors (e.g., De Silva, Jeitschko, and Kosmopoulou, 2009) who have examined bidding in highway procurement auctions have combined all the data into one market bidding regression. This approach makes sense if each firm faces similar market conditions in a fairly thick bidding market. As we have argued, however, some parts of the state have market characteristics that are conducive to competitive bidding, whereas the rest of the state might be susceptible to collusive bidding. The Louisville and northern Kentucky market areas have dense public road networks, considerable private commercial paving work, and numerous asphalt paving companies. Other regions of Kentucky have fewer paving companies, largely because of sparser road networks and fewer private paving jobs.

\section{Summary Statistics}

Since we are trying to test for a specific form of collusive behavior, we estimate reduced form participation and pricing regressions, first for the entire sample of firms, and then separately for firms bidding in Louisville and northern Kentucky and for firms bidding in the rest of the state. Table 3 contains summary statistics for the variables used in the regression analysis, including measures of pricing, distance, jobs under contract, potential competitors, number of bidders, number of bid proposals purchased, and county identifier variables. There were 1,465 bids submitted on KYTC asphalt projects during the sample period, 270 of which were submitted in the Louisville and northern Kentucky regions and 1,195 of which were submitted in the rest of 
Table 3: Summary Statistics for All Counties, Competitive Counties, and Non-competitive Counties

\begin{tabular}{|c|c|c|c|}
\hline VARIABLES & $\begin{array}{c}(1) \\
\text { All } \\
\text { Counties } \\
(n=1,465)\end{array}$ & $\begin{array}{c}(2) \\
\text { Competitive } \\
\text { Counties } \\
(\mathrm{n}=270)\end{array}$ & $\begin{array}{c}(3) \\
\text { Non-competitive } \\
\text { Counties } \\
(\mathrm{n}=1,195)\end{array}$ \\
\hline Pricing (Bid Value/Engineer's Est.) & $\begin{array}{c}0.957 \\
(0.120)\end{array}$ & $\begin{array}{c}0.883 \\
(0.0941)\end{array}$ & $\begin{array}{c}0.974 \\
(0.119)\end{array}$ \\
\hline Distance (0 to 10 miles) & $\begin{array}{c}0.324 \\
(0.468)\end{array}$ & $\begin{array}{c}0.448 \\
(0.498)\end{array}$ & $\begin{array}{c}0.295 \\
(0.456)\end{array}$ \\
\hline Distance (11 to 20 miles) & $\begin{array}{c}0.375 \\
(0.484)\end{array}$ & $\begin{array}{c}0.404 \\
(0.492)\end{array}$ & $\begin{array}{c}0.369 \\
(0.483)\end{array}$ \\
\hline Distance (21 to 30 miles) & $\begin{array}{c}0.205 \\
(0.404)\end{array}$ & $\begin{array}{c}0.119 \\
(0.324)\end{array}$ & $\begin{array}{c}0.225 \\
(0.418)\end{array}$ \\
\hline Distance (31 to 40 miles) & $\begin{array}{l}0.0696 \\
(0.255)\end{array}$ & $\begin{array}{l}0.0296 \\
(0.17)\end{array}$ & $\begin{array}{l}0.0787 \\
(0.269)\end{array}$ \\
\hline Distance (41 to 50 miles) & $\begin{array}{l}0.0239 \\
(0.153)\end{array}$ & $\begin{array}{l}- \\
-\end{array}$ & $\begin{array}{l}0.0293 \\
(0.169)\end{array}$ \\
\hline Distance (51 to 60 miles) & $\begin{array}{l}0.00205 \\
(0.0452)\end{array}$ & $\begin{array}{l}- \\
-\end{array}$ & $\begin{array}{l}0.00251 \\
(0.0501)\end{array}$ \\
\hline Jobs Under Contract & $\begin{array}{c}5.214 \\
(4.261)\end{array}$ & $\begin{array}{c}2.426 \\
(2.716)\end{array}$ & $\begin{array}{c}5.844 \\
(4.295)\end{array}$ \\
\hline Potential Competitors & $\begin{array}{c}6.550 \\
(3.367)\end{array}$ & $\begin{array}{c}7.67 \\
(2.326)\end{array}$ & $\begin{array}{c}6.297 \\
(3.512)\end{array}$ \\
\hline Number of Bidders & $\begin{array}{c}1.756 \\
(0.853)\end{array}$ & $\begin{array}{c}2.826 \\
(0.811)\end{array}$ & $\begin{array}{c}1.514 \\
(0.653)\end{array}$ \\
\hline One Bidder & $\begin{array}{c}0.462 \\
(0.499)\end{array}$ & $\begin{array}{l}0.0444 \\
(0.206)\end{array}$ & $\begin{array}{c}0.556 \\
(0.497)\end{array}$ \\
\hline Two Bidders & $\begin{array}{c}0.369 \\
(0.483)\end{array}$ & $\begin{array}{c}0.27 \\
(0.445)\end{array}$ & $\begin{array}{c}0.391 \\
(0.488)\end{array}$ \\
\hline Three Bidders & $\begin{array}{c}0.126 \\
(0.332)\end{array}$ & $\begin{array}{l}0.526 \\
(0.5)\end{array}$ & $\begin{array}{l}0.0351 \\
(0.184)\end{array}$ \\
\hline Four Bidders & $\begin{array}{l}0.0389 \\
(0.193)\end{array}$ & $\begin{array}{c}0.133 \\
(0.341)\end{array}$ & $\begin{array}{l}0.0176 \\
(0.131)\end{array}$ \\
\hline Five Bidders & $\begin{array}{l}0.00478 \\
(0.0690)\end{array}$ & $\begin{array}{l}0.0259 \\
(0.159)\end{array}$ & $\begin{array}{l}- \\
-\end{array}$ \\
\hline One Bid Proposal Purchased & $\begin{array}{c}0.403 \\
(0.491)\end{array}$ & $\begin{array}{l}0.0222 \\
(0.148)\end{array}$ & $\begin{array}{l}0.49 \\
(0.5)\end{array}$ \\
\hline Two Bid Proposal Purchased & $\begin{array}{c}0.371 \\
(0.483)\end{array}$ & $\begin{array}{c}0.215 \\
(0.411)\end{array}$ & $\begin{array}{c}0.406 \\
(0.491)\end{array}$ \\
\hline Three Bid Proposal Purchased & $\begin{array}{c}0.154 \\
(0.361)\end{array}$ & $\begin{array}{c}0.496 \\
(0.501)\end{array}$ & $\begin{array}{c}0.077 \\
(0.267)\end{array}$ \\
\hline Four Bid Proposal Purchased & $\begin{array}{l}0.0491 \\
(0.216)\end{array}$ & $\begin{array}{c}0.193 \\
(0.395)\end{array}$ & $\begin{array}{l}0.0167 \\
(0.128)\end{array}$ \\
\hline
\end{tabular}


Table 3 (continued)

\begin{tabular}{|c|c|c|c|}
\hline VARIABLES & $\begin{array}{c}(1) \\
\text { All } \\
\text { Counties } \\
(\mathrm{n}=1,465)\end{array}$ & $\begin{array}{c}(2) \\
\text { Competitive } \\
\text { Counties } \\
(\mathrm{n}=270)\end{array}$ & $\begin{array}{c}(3) \\
\text { Non-competitive } \\
\text { Counties } \\
(\mathrm{n}=1,195)\end{array}$ \\
\hline Five Bid Proposal Purchased & $\begin{array}{l}0.0171 \\
(0.130)\end{array}$ & $\begin{array}{c}0.0667 \\
(0.25)\end{array}$ & $\begin{array}{c}0.00586 \\
(0.0763)\end{array}$ \\
\hline Six Bid Proposal Purchased & $\begin{array}{l}0.00546 \\
(0.0737)\end{array}$ & $\begin{array}{l}0.00741 \\
(0.0859)\end{array}$ & $\begin{array}{l}0.00502 \\
(0.0707)\end{array}$ \\
\hline Project in same county-no rival & $\begin{array}{c}0.438 \\
(0.496)\end{array}$ & $\begin{array}{c}0.219 \\
(0.414)\end{array}$ & $\begin{array}{c}0.488 \\
(0.5)\end{array}$ \\
\hline Project in same county-rival & $\begin{array}{c}0.140 \\
(0.347)\end{array}$ & $\begin{array}{c}0.374 \\
(0.485)\end{array}$ & $\begin{array}{c}0.087 \\
(0.282)\end{array}$ \\
\hline Project in adjacent county-no rival & $\begin{array}{c}0.297 \\
(0.457)\end{array}$ & $\begin{array}{c}0.185 \\
(0.389)\end{array}$ & $\begin{array}{c}0.322 \\
(0.468)\end{array}$ \\
\hline Project in adjacent county-rival & $\begin{array}{c}0.125 \\
(0.331)\end{array}$ & $\begin{array}{c}0.222 \\
(0.417)\end{array}$ & $\begin{array}{c}0.103 \\
(0.304)\end{array}$ \\
\hline
\end{tabular}

the state. Column (1) contains all bids; column (2) contains bids submitted for projects in the competitive market areas surrounding Louisville and northern Kentucky; and column (3) contains bids submitted in the rest of the state.

Significant differences between the competitive and noncompetitive regions are immediately evident. The ratio of the bid price to the state engineer's official estimate of the project cost averaged 88 percent in Louisville and northern Kentucky, versus 97 percent in the rest of the state. The average number of bidders on projects in Louisville and northern Kentucky was 2.8 , versus 1.5 for the rest of the state. Four percent of projects attracted only a single bidder in competitive regions, whereas 56 percent of projects had only one bidder in noncompetitive regions. Eighty-five percent of bids were on projects located within 20 miles of the plant in competitive regions, while 66 percent of bids were within a 20-mile radius in noncompetitive regions. Finally, only 22 percent of projects were located in a county with only one asphalt plant 
in the Louisville and northern Kentucky markets, while 49 percent of projects were in singleplant counties in the rest of the state.

\section{Whether to Bid-the Participation Decision}

All of the projects in each firm's potential service area are included in the analysis of bidding behavior. Each individual project located in a firm's service area is a unit of observation. The dependent variable is the behavior we are trying to understand — whether a firm bids on a project that it can feasibly carry out. Expected profits are the obvious starting point, so we analyze factors that are likely to affect the expected profitability of a project. These include cost factors such as distance from plant to project, the number of projects a firm has under contract, and the size of the project. Since firms are competing in a repeated game, strategic factors such as how many firms purchased bid proposals and how many other firms also have the project in their service territories and hence could potentially carry out the project are also included. In a separate specification, county variables are added to see if county boundaries have explanatory power apart from distance, which would be consistent with county boundaries serving as focal points for firms to coordinate their bidding.

Distance is a major determinant of costs in asphalt paving, and so we would expect the distance variable to be highly important in the firm's bidding decision. ${ }^{36}$ After determining projects falling within the firm's service area, we calculated the driving distance from the plant to the project using the OD Cost Matrix function in ArcMap. This mapping function calculates the shortest driving distance from a plant to each project in the service area using maps publicly available from the Kentucky Transportation Cabinet.

${ }^{36}$ See, for example, Bajari and Ye (2003) and De Silva, Dunne, and Kosmopoulou (2003). 
Capacity utilization may affect a firm's decision to bid on a project. If a firm is at or close to capacity, the cost of taking on additional work will be increased. ${ }^{37}$ We construct this variable by determining the number of projects the firm is currently working on (falling between the beginning and ending date) on the day of bidding. For example, Mountain Enterprises bid on a project on November 11, 2007. A search of the awarded contract data indicates that the firm had seven projects under contract on that day. This exercise was replicated for each project for each firm.

Heterogeneity between projects is captured using the state engineer's estimate of the cost of the job. This variable serves as an indicator of the scale of the job. ${ }^{38}$ It also lends insight into the types of projects firms are willing to bid on. In thicker markets some firms target large-scale high-value projects while others concentrate on smaller projects. In thinner markets firms tend to bid on all jobs put out for bid by KYTC.

Two other variables capture competitive and strategic effects. The first measures the number of rival firms that purchased official bid proposals for the project. We include this variable to see if knowledge that other firms have expressed an interest in bidding on the project reduces or increases the probability of bidding. This variable captures a strategic element of bidding that may result when firms know in advance which of their rivals (if any) will participate in the auction. The second variable counts the number of other competitors whose 60-mile service areas contain the specific project. This variable captures a somewhat different strategic

\footnotetext{
${ }^{37}$ See, for example, Jofre-Bonet and Pesendorfer (2003) and De Silva, Kosmopoulou, and Lamarche (2009). In an interview, KYTC officials expressed that they do not see capacity constraints as an issue, since they schedule projects specifically not to create capacity problems for likely bidders.

${ }^{38}$ See, for example, De Silva, Jeitschko, and Kosmopoulou (2009).
} 
effect - the number of potential competitors the firm faces in its long-run supply of asphalt in a geographic market.

Initially a probit model was used, following De Silva, Jeitschko, and Kosmopoulou (2009). Problems with that approach arise, however, because there are a number of firms that tend to bid only in their specific counties ${ }^{39}$ Linear probability models are a possible alternative, because they provide a linear approximation to whatever underlying model is present and allow the fixed effects to stay in the model regardless of the pattern of bidding. While the linear probability model is controversial because of its range (fitted values outside 0,1 ), there is a tradeoff between this problem and those discussed in the previous footnote. Theoretically, the fixed effects in a probit model apply to the propensity score. If the firm does not bid at all in a county the propensity score, which is abstract and unobserved, is negative infinity. That makes no sense - surely there is some nonzero probability of bidding — but the probit model requires this result. The linear probability model only calculates that the probability of bidding is low, which is more realistic. For this reason we present results using linear probability models to estimate the bidding participation decision. ${ }^{40}$

The sample includes any asphalt project put out for bid from 2005 to 2007 within each firm's 60-mile service area, aggregated over all 31 firms in the state. The dependent variable $(y=$

\footnotetext{
${ }^{39}$ The probits we ran with fixed effects of counties are subject to two problems, both of which potentially bias the results in important ways. First, the fixed effects are estimated on small samples, and they cannot be differenced out in a non-linear model like probit. The fact that fixed effects are inconsistent creates bias for the whole model. The inconsistency arises from the lack of variance going to zero, as the county sample does not grow. Second, perfect classification, in which a firm either always or never bids in a county, eliminates the county variables and the software drops these variables out of the model. Some firms are affected a lot by this, others very little. This creates, in effect, a selection bias because firms are not bidding in some counties, which then drop out of the sample rather than staying in with some sort of coefficient. Neither of these problems can be eliminated if probit, logit, or any other non-linear model is used. They constitute unfortunate but unavoidable problems in combining limited dependent variables and fixed effects.

40 J. S. Butler and Chris Bollinger added invaluable insights into reasons why the linear probability model is the preferred approach for this particular analysis.
} 
1 if the firm bids, $y=0$ otherwise) is whether the firm bids on a specific project. The first independent variable consists of 10-mile categorical dummy variables for distance (Distance). ${ }^{41}$ The reference category is the distance ring 0-10 miles. The next variable is Jobs Under Contract, which controls for the number of projects a firm has currently under contract from KYTC when it bids on a project. The Engineer's Estimate is included to control for costs and size of the projects and other heterogeneity associated with each project. Potential Competitors indicates how many other firms have the project within their 60-mile service area and could feasibly bid on the project as well. The Bid Proposal variable consists of a set of categorical dummy variables indicating how many other firms have purchased bid proposals for that particular project. Equation (A) expresses this first specification of the bid participation regression:

$$
y=\beta_{0}+\beta_{1}(\text { Distance })+\beta_{2}(\text { Jobs Under Contract })+\beta_{3}(\text { Engineer's Estimate })+
$$$$
\left.+\beta_{4} \text { (PotentialCompetitors }\right)+\beta_{5}(\text { Bid Proposals })+\varepsilon
$$

In a market environment with geographically dispersed asphalt firms, geographically dispersed paving projects, and no political boundaries defining the location of projects and firms, we would expect the cost variables, especially distance, to be significant determinants of bidding behavior. We would expect the competitive/strategic variables to play a bigger role in thinner markets than in thicker markets. In such an environment with no obvious focal point, it would be difficult for firms to coordinate their bidding absent overt communication.

In a market environment where firms and projects are defined by their location inside or outside certain political boundaries, such as county lines in Kentucky, firms may be able to

\footnotetext{
${ }^{41} \mathrm{We}$ also estimated bid functions using distance and distance squared. These results were similar to the results with the categorical variables.
} 
coordinate their bidding, especially when only a few are involved. In that case, location relative to political boundaries would take on greater importance in predicting bidding behavior, and actual distance from plant to project may take on lesser importance. To test for the importance of these political boundary-location effects, we expand the specification of the bid participation regression as follows:

$$
\begin{aligned}
& y=\beta_{0}+\beta_{1}(\text { Distance })+\beta_{2}(\text { Jobs Under Contract })+\beta_{3}(\text { Engineer's Estimate })+ \\
& +\beta_{4}(\text { PotentialCompetitors })+\beta_{5}(\text { Bid Proposals })+\beta_{6}(\text { County }: \text { All })+\varepsilon
\end{aligned}
$$

The County: All variable is a set of dummy variables that captures the four scenarios depicted in Figure 2. Project in same county-no rival (depicted as county A in Figure 2) is the reference category and is excluded from the regression. This variable indicates that a project is located in a county where the firm has an asphalt plant, and where no rival firms have an asphalt plant. Project in same county-rival (depicted as county $\mathrm{C}$ in Figure 2) indicates a project that is in the same county, and a rival firm also has an asphalt plant in that county. Project in adjacent county-rival (depicted as county B in Figure 2) indicates a project that is in an adjacent county, and a rival firm has an asphalt plant in the county. Project in adjacent county-no rival (depicted as county $\mathrm{D}$ in Figure 2) indicates that a project is in an adjacent county that does not have an asphalt plant in the county.

If in a thin market firms are able to use county boundaries to coordinate bids, these variables will allow us to identify such behavior. If firms X and Y in counties A and B in Figure 2 are able to coordinate their participation decisions by only bidding within their own county and refraining from bidding in their rival's county, then the Project in adjacent county-rival variable will be negative and significant, all else constant. This result would mean that, even after controlling for distance and other factors, a firm is less likely to bid on a project simply because 
it is in a county where a rival has an asphalt plant. This result would therefore support a conclusion that firms are tacitly colluding in bidding and "respecting" one another's turf.

\section{How Much to Bid-the Pricing Decision}

Once a firm decides to participate in a particular auction, it must formulate a bid. All of the bids submitted on all projects during the sample period are included in our analysis of pricing behavior. Each individual bid is a unit of observation. The dependent variable is the behavior we are trying to understand - how much a firm chooses to bid on a project that it can feasibly carry out. So that we can compare across projects of different magnitudes, we express the firm's bid as a proportion of the state highway engineer's official estimate of the cost of completing the project.

In explaining how much firms choose to bid, expected profits again are the obvious starting point, so we analyze factors that are likely to affect the expected profitability of winning the bid and carrying out the project. These include cost factors such as distance from plant to project, the number of projects a firm has under contract, and the size of the project. Since firms are competing in a repeated game, strategic factors such as how many rival firms also have the project in their service areas are also included.

Instead of bid proposals purchased, we use the number of bidders to capture actual competition. Firms know in advance of submitting their bid the number and identity of any other firms that have purchased a bid proposal. In competitive auctions, multiple plans are purchased 
and firms fully expect to face rival bidders. In less-competitive markets in Kentucky, roughly half the time firms know they will be the only bidder in advance of turning in their bid. ${ }^{42}$

Another strategic element in the pricing decision is the magnitude of the cost advantage or disadvantage due to distance, which is most likely to come into play in thin markets where firms have identifiable rivals whose costs they can easily estimate. Accordingly, we include a variable measuring the difference in distance to the project between the bidder's plant and the next closest rival plant. ${ }^{43}$ Lastly, county identifier variables are added to see if firms bid differently when on home turf, a rival firm's turf, or unclaimed territory.

\section{Empirical Results}

We first construct some simple cross tabulations to determine whether any bid coordination via refraining from bidding seems to occur. When counties are classified according to type as in Figure 2, the number and percent of projects that attract only one, two, three, four, or five bidders is as follows:

Number of projects classified by number of bidders and county types

\begin{tabular}{|c|c|c|c|c|c|c|}
\cline { 2 - 7 } \multicolumn{1}{c|}{} & \multicolumn{7}{c|}{ Number of Bidders } \\
\hline County Type & $\mathbf{1}$ & $\mathbf{2}$ & $\mathbf{3}$ & $\mathbf{4}$ & $\mathbf{5}$ & Total \\
\hline A/B & 494 & 137 & 28 & 3 & 1 & 663 \\
& $(74.5 \%$ & $(20.7 \%$ & $(4.2 \%)$ & $(0.5 \%)$ & $(0.2 \%$ & $(100 \%)$ \\
\hline $\mathbf{C}$ & 28 & 46 & 20 & 16 & 2 & 112 \\
& $(25.0 \%)$ & $(41.1 \%)$ & $(17.9 \%)$ & $(14.3 \%)$ & $(1.8 \%)$ & \\
\hline D & 155 & 101 & 24 & 5 & 0 & 285 \\
& $(54.4 \%)$ & $(35.4 \%)$ & $(8.4 \%)$ & $(1.8 \%)$ & & \\
\hline Total & 677 & 284 & 72 & 24 & 3 & 1060 \\
\hline
\end{tabular}

\footnotetext{
${ }^{42}$ In the rare instance when a firm is uncertain whether a rival is actually going to follow up its purchase of a bid proposal by actually submitting a bid, the incumbent can easily carry two bid envelopes to the bid closing and see whether its rival shows up and turns in a bid. We also estimated the pricing equations using the number of bid proposals purchased, with no significant effect on the regression results.

${ }^{43}$ This distance differential is positive (negative) if the rival plant is farther away from (closer to) the project.
} 
As is evident, projects located in counties where only one asphalt company has a plant (types A and B) are relatively more likely to attract only one bidder than projects located in counties where multiple companies have plants (type C) or no companies have plants (type D).

A finer distinction can be drawn by focusing on projects where there are only two firms in close proximity. We restrict our attention to projects where there are only two firms with an asphalt plant located within 30 miles and where the distance differential between the two plants is less than 10 miles. To determine whether bid coordination via county boundaries is occurring, we also categorize projects according to county type. In type A/B counties, firm $\mathrm{X}$ owns the plant in the county and firm Y owns the plant in an adjacent county. In type C and type D counties, firm $\mathrm{X}$ has the nearer plant:

Number of Projects Firms X and Y Bid On by County Type

\begin{tabular}{|c|c|c|c|c|}
\hline County Type & Firm X & Firm Y & $\begin{array}{c}\text { Total Number } \\
\text { of Projects }\end{array}$ \\
\hline A/B & $\begin{array}{c}65 \\
(98.5 \%)\end{array}$ & $\begin{array}{c}14 \\
(21.2 \%)\end{array}$ & 66 \\
\hline C & $\begin{array}{c}25 \\
(65.8 \%)\end{array}$ & $\begin{array}{c}33 \\
(86.8 \%)\end{array}$ & 38 \\
\hline D & $\begin{array}{c}58 \\
(89.2 \%)\end{array}$ & $\begin{array}{c}34 \\
(52.3 \%)\end{array}$ & 63 \\
\hline
\end{tabular}

Again, county boundaries seem to drive bidding decisions. When neither firm has a sizeable distance advantage but the project is located in the same county as one firm's plant but not the other's, the outsider (firm Y) avoids encroaching on the insider's (firm X) turf. On the other hand, when both firms are insiders (county type C) or both firms are outsiders (county type D), there is no clear focal point delineating each firm's turf and both firms are very likely to bid. 


\section{Whether to Bid-the Participation Decision}

While these simple cross tabulations are informative, other factors affect firms' bid participation decisions. Table 4 contains the results of the participation decision regressions. The first two columns contain results for all counties; the third and fourth columns contain results for the thicker market areas around Louisville and northern Kentucky; and the fifth and sixth columns contain results for potentially less competitive counties in the rest of the state. In each case we include specifications first without, and then with, county identifier dummies.

The first column represents the most general specification —all firms in all counties, with no county identifier dummies - and turns up statistically significant regression coefficients with the expected signs. Distance is highly significant - firms are increasingly less likely to bid as distance from the project to the firm's asphalt plant increases from zero to 30 miles. The distance effect tapers off after 30 miles, reflecting that very few firms bid on projects that far from their plant. Having more jobs currently under contract reduces the likelihood of bidding. Larger jobs attract fewer bidders. More potential competitors reduce the likelihood that a firm submits a bid. Finally, when the firm knows in advance that other firms have purchased bid plans, the likelihood of bidding drops significantly.

The second column regression uses the same sample as the first - competitive and Noncompetitive counties together—but adds county identifier dummies. Results for other variables are generally similar, except that the inclusion of county identifier dummies reduces the coefficient magnitudes for the distance buckets. Coefficients on the county variables indicate that there is essentially no difference in the likelihood of bidding on projects located in the county where the firm's asphalt plant is located, whether or not another firm has a plant in that same 
county. The likelihood of bidding in an adjacent county is reduced even if there is no rival plant in that county, and is further reduced if another firm has a plant located in that county.

Market conditions in Louisville and northern Kentucky differ from the rest of the state, as indicated by comparisons of basic summary statistics in Table 3 . Results for bidding participation regressions in these competitive markets are contained in columns (3) and (4) of Table 4. Distance is a significant determinant of the likelihood of bidding. Jobs under contract, the engineer's estimate of the cost of the job, and the number of potential competitors are not statistically significant factors. When county identifier variables are added, the presence of another likely bidder, as indicated by one other bid proposal being purchased, does not deter bidding. Firms are more likely to bid in their own county than in an adjacent county, whether or not a rival firm has an asphalt plant in the same county or in the adjacent county.

Regression results for noncompetitive counties where market conditions are more conducive to collusion are contained in columns (5) and (6). Distance is still a statistically significant determinant of the likelihood of bidding, but the magnitudes of the regression coefficients are roughly half the size of those for Louisville and northern Kentucky displayed in columns (3) and (4). The presence of even one likely other bidder, as indicated by bid proposals purchased, greatly reduces the likelihood that a firm submits a bid. The county identifier variables suggest the following pattern of bidding behavior in less competitive markets: (a) bid if the project is in the same county as your plant, regardless of whether there is a rival plant in the county; (b) maybe bid if the project is in an adjacent county with no rival firms; and (c) avoid bidding if the project is in an adjacent county where a rival firm has a plant.

These results suggest that county boundaries do influence firms' bid participation decisions, more so in thinner markets where firms' service areas only partially overlap than in 
thicker markets with multiple bidders. Controlling for distance, a firm is much more likely to bid on a project if it is located in its home county than it is to bid if the project is located in an adjacent county where a rival firm has a plant.

\section{How Much to Bid-the Pricing Decision}

Table 5 contains results of the reduced form pricing regressions, first for all counties and then for competitive counties and noncompetitive counties. Specifications without and with county identifier dummy variables are included. The dependent variable is expressed as the ratio of the firm's bid to the engineer's estimate of the cost of the project. We use the actual number of bidders instead of bid proposals purchased in the pricing regressions, and we also include a variable measuring the distance differential between the firm and the (next) closest rival to the project. $^{44}$

The distance buckets generally are not statistically significant; however, the distance differential variable is negative and highly significant. Controlling for other factors, when a firm has a 10-mile distance advantage over its next closest rival, it bids roughly 2 percent higher than when there is no cost advantage due to greater proximity. The number of firms whose service territories include the project (potential competitors) does reduce the bid price submitted, but while statistically significant, the economic importance is small. These results do not differ between competitive and noncompetitive counties. With the number of bidders and the county identifier variables, however, stark differences occur between the competitive and noncompetitive regions of the state.

${ }^{44}$ Results are essentially unchanged if we use bid proposals purchased rather than number of bidders. 
Table 4: Participation Regressions (Whether to Bid) for All Counties, Competitive Counties, and Non-competitive Counties

\begin{tabular}{|c|c|c|c|c|c|c|}
\hline VARIABLES & (1) & $(2)$ & (3) & (4) & (5) & (6) \\
\hline $\begin{array}{l}\text { Dependent Variable: } \\
\text { Bid or Not on Project } \\
(\mathrm{Bid}=1)\end{array}$ & All Counties & $\begin{array}{l}\text { All Counties } \\
\text { w/County } \\
\text { Dummies }\end{array}$ & $\begin{array}{l}\text { Competitive } \\
\text { Counties }\end{array}$ & $\begin{array}{c}\text { Competitive } \\
\text { Counties } \\
\text { w/County Dummies }\end{array}$ & $\begin{array}{l}\text { Non- } \\
\text { competitive } \\
\text { Counties }\end{array}$ & $\begin{array}{l}\text { Non-competitive } \\
\text { Counties } \\
\text { w/County Dummies }\end{array}$ \\
\hline Distance (11 to 20 miles) & $\begin{array}{l}-0.208 * * * \\
(0.0192)\end{array}$ & $\begin{array}{c}-0.0930 * * * \\
(0.0189)\end{array}$ & $\begin{array}{c}-0.374 * * * \\
(0.0405)\end{array}$ & $\begin{array}{c}-0.215 * * * \\
(0.0396)\end{array}$ & $\begin{array}{c}-0.133 * * * \\
(0.0212)\end{array}$ & $\begin{array}{l}-0.0380 * \\
(0.0196)\end{array}$ \\
\hline Distance (21 to 30 miles) & $\begin{array}{c}-0.443 * * * \\
(0.0197)\end{array}$ & $\begin{array}{c}-0.222 * * * \\
(0.0227)\end{array}$ & $\begin{array}{c}-0.677 * * * \\
(0.0390)\end{array}$ & $\begin{array}{c}-0.354 * * * \\
(0.0497)\end{array}$ & $\begin{array}{c}-0.334 * * * \\
(0.0230)\end{array}$ & $\begin{array}{c}-0.146^{* * * *} \\
(0.0234)\end{array}$ \\
\hline Distance (31 to 40 miles) & $\begin{array}{c}-0.590 * * * \\
(0.0186)\end{array}$ & $\begin{array}{c}-0.353 * * * \\
(0.0223)\end{array}$ & $\begin{array}{c}-0.804 * * * \\
(0.0335)\end{array}$ & $\begin{array}{c}-0.461 * * * \\
(0.0472)\end{array}$ & $\begin{array}{c}-0.479 * * * \\
(0.0227)\end{array}$ & $\begin{array}{c}-0.274 * * * \\
(0.0234)\end{array}$ \\
\hline Distance (41 to 50 miles) & $\begin{array}{c}-0.640 * * * \\
(0.0178)\end{array}$ & $\begin{array}{c}-0.402 * * * \\
(0.0218)\end{array}$ & $\begin{array}{c}-0.849 * * * \\
(0.0287)\end{array}$ & $\begin{array}{c}-0.523 * * * \\
(0.0428)\end{array}$ & $\begin{array}{c}-0.525^{* * * *} \\
(0.0222)\end{array}$ & $\begin{array}{c}-0.318 * * * \\
(0.0229)\end{array}$ \\
\hline Distance (51 to 60 miles) & $\begin{array}{c}-0.656 * * * \\
(0.0175)\end{array}$ & $\begin{array}{c}-0.416 * * * \\
(0.0216)\end{array}$ & $\begin{array}{c}-0.866 * * * \\
(0.0275)\end{array}$ & $\begin{array}{c}-0.531 * * * \\
(0.0427)\end{array}$ & $\begin{array}{c}-0.544 * * * \\
(0.0219)\end{array}$ & $\begin{array}{c}-0.336 * * * \\
(0.0227)\end{array}$ \\
\hline Jobs Under Contract & $\begin{array}{c}-0.00187 * * \\
(0.000765)\end{array}$ & $\begin{array}{l}-0.00127 * \\
(0.000703)\end{array}$ & $\begin{array}{l}-0.00398 \\
(0.00248)\end{array}$ & $\begin{array}{l}0.000154 \\
(0.00223)\end{array}$ & $\begin{array}{l}-0.000648 \\
(0.000789)\end{array}$ & $\begin{array}{l}-0.000373 \\
(0.000734)\end{array}$ \\
\hline Engineer's Estimate & $\begin{array}{c}-5.58 \mathrm{e}-09 * * * \\
(1.93 \mathrm{e}-09)\end{array}$ & $\begin{array}{c}-3.90 \mathrm{e}-09 * * \\
(1.58 \mathrm{e}-09)\end{array}$ & $\begin{array}{l}-1.61 \mathrm{e}-08 \\
(1.26 \mathrm{e}-08)\end{array}$ & $\begin{array}{l}-1.16 \mathrm{e}-08 \\
(1.26 \mathrm{e}-08)\end{array}$ & $\begin{array}{c}-4.93 \mathrm{e}-09 * * \\
(1.96 \mathrm{e}-09)\end{array}$ & $\begin{array}{l}-2.83 \mathrm{e}-09^{*} \\
(1.59 \mathrm{e}-09)\end{array}$ \\
\hline Potential Competitors & $\begin{array}{c}-0.0193 * * * \\
(0.000952)\end{array}$ & $\begin{array}{l}-0.0136 * * * \\
(0.000912)\end{array}$ & $\begin{array}{l}-0.00665^{*} \\
(0.00388)\end{array}$ & $\begin{array}{l}-0.00306 \\
(0.00376)\end{array}$ & $\begin{array}{l}-0.0194 * * * \\
(0.000977)\end{array}$ & $\begin{array}{l}-0.0141 * * * \\
(0.000938)\end{array}$ \\
\hline $\begin{array}{l}\text { One competitive bid } \\
\text { proposal purchased }\end{array}$ & $\begin{array}{c}-0.464 * * * \\
(0.0141)\end{array}$ & $\begin{array}{c}-0.353 * * * \\
(0.0171)\end{array}$ & $\begin{array}{c}-0.279 * * * \\
(0.0638)\end{array}$ & $\begin{array}{l}-0.0173 \\
(0.0475)\end{array}$ & $\begin{array}{c}-0.520 * * * \\
(0.0159)\end{array}$ & $\begin{array}{c}-0.403 * * * \\
(0.0184)\end{array}$ \\
\hline $\begin{array}{l}\text { Two competitive bid } \\
\text { proposals purchased }\end{array}$ & $\begin{array}{c}-0.478 * * * \\
(0.0148)\end{array}$ & $\begin{array}{c}-0.383 * * * \\
(0.0180)\end{array}$ & $\begin{array}{c}-0.403 * * * \\
(0.0610)\end{array}$ & $\begin{array}{l}-0.109 * * \\
(0.0509)\end{array}$ & $\begin{array}{c}-0.558 * * * \\
(0.0167)\end{array}$ & $\begin{array}{c}-0.463 * * * \\
(0.0191)\end{array}$ \\
\hline $\begin{array}{l}\text { Three or more competitive } \\
\text { bid proposals purchased }\end{array}$ & $\begin{array}{c}-0.503 * * * \\
(0.0159)\end{array}$ & $\begin{array}{c}-0.386 * * * \\
(0.0187)\end{array}$ & $\begin{array}{c}-0.540 * * * \\
(0.0616)\end{array}$ & $\begin{array}{l}-0.243 * * * \\
(0.0517)\end{array}$ & $\begin{array}{l}-0.515^{* * * *} \\
(0.0216)\end{array}$ & $\begin{array}{c}-0.407 * * * \\
(0.0231)\end{array}$ \\
\hline $\begin{array}{l}\text { Project in same county- } \\
\text { rival }\end{array}$ & & $\begin{array}{c}0.0751^{* *} \\
(0.0295)\end{array}$ & & $\begin{array}{l}-0.0504 \\
(0.0465)\end{array}$ & & $\begin{array}{c}0.0529 \\
(0.0394)\end{array}$ \\
\hline $\begin{array}{l}\text { Project in adjacent county- } \\
\text { no rival }\end{array}$ & & $\begin{array}{c}-0.232 * * * \\
(0.0213)\end{array}$ & & $\begin{array}{c}-0.315 * * * \\
(0.0494)\end{array}$ & & $\begin{array}{c}-0.218 * * * \\
(0.0221)\end{array}$ \\
\hline
\end{tabular}


Table 4 (continued)

\begin{tabular}{|c|c|c|c|c|c|c|}
\hline VARIABLES & $(1)$ & $(2)$ & $(3)$ & $(4)$ & $(5)$ & $(6)$ \\
\hline Dependent Variable: & All Counties & All Counties & Competitive & Competitive & Non- & Non-competitive \\
\hline Bid or Not on Project & & w/County & Counties & Counties & competitive & Counties \\
\hline$(\mathrm{Bid}=1)$ & & Dummies & & w/County Dummies & Counties & w/County Dummies \\
\hline Project in adjacent county- & & $-0.356^{* * *}$ & & $-0.486^{* * *}$ & & $-0.344 * * *$ \\
\hline rival & & $(0.0214)$ & & $(0.0458)$ & & $(0.0221)$ \\
\hline \multirow[t]{2}{*}{ Constant } & $1.312 * * *$ & $1.234 * * *$ & $1.415 * * *$ & $1.215^{* * *}$ & $1.252 * * *$ & $1.191 * * *$ \\
\hline & $(0.0153)$ & $(0.0145)$ & $(0.0733)$ & $(0.0612)$ & $(0.0158)$ & $(0.0146)$ \\
\hline Observations & 6,933 & 6,933 & 1,009 & 1,009 & 5,924 & 5,924 \\
\hline R-squared & 0.574 & 0.620 & 0.575 & 0.641 & 0.595 & 0.635 \\
\hline
\end{tabular}

Notes: Robust standard errors in parentheses; Reference Category (distance variables): Distance ( 0 to 10 miles); Reference Category (Bid props): 0 competitive bid proposals purchased; Reference Category (counties): Project in same county-no rival; *** $\mathrm{p}<0.01,{ }^{*} \mathrm{p}<0.05,{ }^{*} \mathrm{p}<0.1$

Table 5: Pricing Regressions-Bid Price as a Proportion of Engineer's Estimate of Cost for All Counties, Competitive Counties, and Non-competitive Counties

\begin{tabular}{|c|c|c|c|c|c|c|}
\hline $\begin{array}{l}\text { VARIABLES } \\
\text { Dependent Variable: } \\
\text { Bid Value/Engineer's } \\
\text { Est. }\end{array}$ & $\begin{array}{c}(1) \\
\text { All Counties }\end{array}$ & $\begin{array}{l}\text { (2) } \\
\text { All Counties } \\
\text { w/ County } \\
\text { Dummies }\end{array}$ & $\begin{array}{l}(3) \\
\text { Competitive } \\
\text { Counties }\end{array}$ & $\begin{array}{c}\text { (4) } \\
\text { Competitive } \\
\text { Counties } \\
\text { w/ County } \\
\text { Dummies }\end{array}$ & $\begin{array}{c}(5) \\
\text { Non- } \\
\text { competitive } \\
\text { Counties }\end{array}$ & $\begin{array}{c}(6) \\
\text { Non-competitive } \\
\text { Counties } \\
\text { w/ County } \\
\text { Dummies }\end{array}$ \\
\hline $\begin{array}{l}\text { Distance } \\
\text { (11 to } 20 \text { miles })\end{array}$ & $\begin{array}{c}0.00272 \\
(0.00583)\end{array}$ & $\begin{array}{c}0.00147 \\
(0.00589)\end{array}$ & $\begin{array}{c}0.0299 * * \\
(0.0123)\end{array}$ & $\begin{array}{c}0.0317 * * \\
(0.0125)\end{array}$ & $\begin{array}{l}-0.00394 \\
(0.00657)\end{array}$ & $\begin{array}{l}-0.00541 \\
(0.00673)\end{array}$ \\
\hline $\begin{array}{l}\text { Distance } \\
\text { (21 to } 30 \text { miles) }\end{array}$ & $\begin{array}{c}0.0143 * \\
(0.00751)\end{array}$ & $\begin{array}{c}0.0101 \\
(0.00811)\end{array}$ & $\begin{array}{c}0.0208 \\
(0.0214)\end{array}$ & $\begin{array}{c}0.0268 \\
(0.0276)\end{array}$ & $\begin{array}{c}0.0125 \\
(0.00816)\end{array}$ & $\begin{array}{c}0.00663 \\
(0.00881)\end{array}$ \\
\hline $\begin{array}{l}\text { Distance } \\
\text { (31 to } 40 \text { miles) }\end{array}$ & $\begin{array}{c}0.0270^{* *} \\
(0.0117)\end{array}$ & $\begin{array}{c}0.0204 \\
(0.0128)\end{array}$ & $\begin{array}{l}-0.0172 \\
(0.0276)\end{array}$ & $\begin{array}{l}-0.0118 \\
(0.0332)\end{array}$ & $\begin{array}{c}0.0304 * * \\
(0.0126)\end{array}$ & $\begin{array}{c}0.0193 \\
(0.0141)\end{array}$ \\
\hline $\begin{array}{l}\text { Distance } \\
\text { (41 to } 50 \text { miles) }\end{array}$ & $\begin{array}{l}0.0464 * \\
(0.0248)\end{array}$ & $\begin{array}{l}0.0421 * \\
(0.0252)\end{array}$ & & & $\begin{array}{l}0.0419 * \\
(0.0251)\end{array}$ & $\begin{array}{c}0.0339 \\
(0.0255)\end{array}$ \\
\hline
\end{tabular}


Table 5 (continued)

\begin{tabular}{|c|c|c|c|c|c|c|}
\hline $\begin{array}{l}\text { VARIABLES } \\
\text { Dependent Variable: } \\
\text { Bid Value/Engineer's } \\
\text { Est. }\end{array}$ & $\begin{array}{c}(1) \\
\text { All Counties }\end{array}$ & $\begin{array}{l}\text { (2) } \\
\text { All Counties } \\
\text { w/ County } \\
\text { Dummies }\end{array}$ & $\begin{array}{l}\text { (3) } \\
\text { Competitive } \\
\text { Counties }\end{array}$ & $\begin{array}{c}\text { (4) } \\
\text { Competitive } \\
\text { Counties } \\
\text { w/ County } \\
\text { Dummies }\end{array}$ & $\begin{array}{c}(5) \\
\text { Non- } \\
\text { competitive } \\
\text { Counties }\end{array}$ & $\begin{array}{c}(6) \\
\text { Non-competitive } \\
\text { Counties } \\
\text { w/ County } \\
\text { Dummies }\end{array}$ \\
\hline $\begin{array}{l}\text { Distance } \\
\text { (51 to } 60 \text { miles })\end{array}$ & $\begin{array}{c}0.140 \\
(0.0999)\end{array}$ & $\begin{array}{c}0.130 \\
(0.0993)\end{array}$ & & & $\begin{array}{c}0.133 \\
(0.101)\end{array}$ & $\begin{array}{c}0.114 \\
(0.0999)\end{array}$ \\
\hline Jobs Under Contract & $\begin{array}{c}-0.00352 * * * \\
(0.000670)\end{array}$ & $\begin{array}{c}-0.00351 * * * \\
(0.000675)\end{array}$ & $\begin{array}{c}-0.00804 * * * \\
(0.00192)\end{array}$ & $\begin{array}{c}-0.00770 * * * \\
(0.00196)\end{array}$ & $\begin{array}{c}-0.00293 * * * \\
(0.000723)\end{array}$ & $\begin{array}{c}-0.00269 * * * \\
(0.000725)\end{array}$ \\
\hline Potential Competitors & $\begin{array}{c}-0.00704 * * * \\
(0.000823)\end{array}$ & $\begin{array}{c}-0.00734 * * * \\
(0.000842)\end{array}$ & $\begin{array}{c}-0.00700^{* *} \\
(0.00275)\end{array}$ & $\begin{array}{r}-0.00575^{*} \\
(0.00308)\end{array}$ & $\begin{array}{c}-0.00627 * * * \\
(0.000874)\end{array}$ & $\begin{array}{c}-0.00646 * * * \\
(0.000886)\end{array}$ \\
\hline $\begin{array}{l}\text { One bidder } \\
\text { (ref: } 3 \text { or more bidders) }\end{array}$ & $\begin{array}{l}0.154 * * * \\
(0.00691)\end{array}$ & $\begin{array}{l}0.147 * * * \\
(0.00791)\end{array}$ & $\begin{array}{l}0.0955^{* * *} \\
(0.0324)\end{array}$ & $\begin{array}{c}0.0934 * * * \\
(0.0352)\end{array}$ & $\begin{array}{c}0.169 * * * \\
(0.0128)\end{array}$ & $\begin{array}{c}0.165 * * * \\
(0.0131)\end{array}$ \\
\hline $\begin{array}{l}\text { Two bidders } \\
\text { (ref: } 3 \text { or more bidders) }\end{array}$ & $\begin{array}{l}0.0195 * * \\
(0.00762)\end{array}$ & $\begin{array}{l}0.0160 * * \\
(0.00777)\end{array}$ & $\begin{array}{l}-0.00216 \\
(0.0135)\end{array}$ & $\begin{array}{l}-0.00136 \\
(0.0151)\end{array}$ & $\begin{array}{c}0.0375 * * * \\
(0.0131)\end{array}$ & $\begin{array}{l}0.0371 * * * \\
(0.0133)\end{array}$ \\
\hline $\begin{array}{l}\text { Project in same county- } \\
\text { rival }\end{array}$ & & $\begin{array}{l}-0.0216 * * \\
(0.00899)\end{array}$ & & $\begin{array}{l}0.00389 \\
(0.0194)\end{array}$ & & $\begin{array}{c}-0.0364 * * * \\
(0.0116)\end{array}$ \\
\hline $\begin{array}{l}\text { Project in adjacent } \\
\text { county-no rival }\end{array}$ & & $\begin{array}{l}-0.00704 \\
(0.00680)\end{array}$ & & $\begin{array}{c}0.0175 \\
(0.0219)\end{array}$ & & $\begin{array}{l}-0.00711 \\
(0.00738)\end{array}$ \\
\hline $\begin{array}{l}\text { Project in adjacent } \\
\text { county-rival }\end{array}$ & & $\begin{array}{c}0.0123 \\
(0.0123)\end{array}$ & & $\begin{array}{l}-0.00483 \\
(0.0257)\end{array}$ & & $\begin{array}{c}0.0340 * * \\
(0.0154)\end{array}$ \\
\hline $\begin{array}{l}\text { Distance difference } \\
\text { between firm and rivals }\end{array}$ & $\begin{array}{c}0.00255^{* * * *} \\
(0.000644)\end{array}$ & $\begin{array}{c}0.00221 * * * \\
(0.000658)\end{array}$ & $\begin{array}{l}0.00181^{*} \\
(0.00102)\end{array}$ & $\begin{array}{l}0.00186^{*} \\
(0.00111)\end{array}$ & $\begin{array}{c}0.00271 * * * \\
(0.000748)\end{array}$ & $\begin{array}{c}0.00195 * * * \\
(0.000733)\end{array}$ \\
\hline Constant & $\begin{array}{l}0.932 * * * \\
(0.00937)\end{array}$ & $\begin{array}{c}0.944 * * * \\
(0.0105)\end{array}$ & $\begin{array}{c}0.935 * * * \\
(0.0212)\end{array}$ & $\begin{array}{c}0.919 * * * \\
(0.0324)\end{array}$ & $\begin{array}{c}0.913 * * * \\
(0.0156)\end{array}$ & $\begin{array}{c}0.921 * * * \\
(0.0157)\end{array}$ \\
\hline $\begin{array}{l}\text { Observations } \\
\text { R-squared }\end{array}$ & $\begin{array}{l}1,465 \\
0.341\end{array}$ & $\begin{array}{l}1,465 \\
0.346\end{array}$ & $\begin{array}{c}270 \\
0.119\end{array}$ & $\begin{array}{c}270 \\
0.123\end{array}$ & $\begin{array}{l}1,195 \\
0.316\end{array}$ & $\begin{array}{l}1,195 \\
0.330\end{array}$ \\
\hline
\end{tabular}

Notes: Robust standard errors in parentheses; Reference Category (distance variables): Distance (0 to 10 miles); Reference Category (bid proposals): Zero competitive bid proposals purchased; Reference Category (counties): Project in same county-no rival; *** $\mathrm{p}<0.01,{ }^{* *} \mathrm{p}<0.05,{ }^{*} \mathrm{p}<0.1$ 
In Louisville and northern Kentucky where market conditions are not conducive to collusion, single-bidder auctions result in price markups that are 9.3 percent higher than when there are two bidders or three or more bidders. Such auctions only occur 4 percent of the time in competitive counties. These results differ markedly from those in the rest of the state where market structure is more conducive to collusion. The price markup in single-bidder auctions in noncompetitive counties, which occur 56 percent of the time, is 16.5 percent greater compared with auctions where there are three or more bidders. When there are two bidders the markup is 3.7 percent greater than auctions with three or more bidders.

In competitive counties bid pricing decisions are not significantly different when a firm is bidding in its own county or an adjacent county, with or without a rival firm present. County boundaries do not affect bid pricing decisions in these markets. In noncompetitive counties, however, bid pricing behavior differs considerably according to county type. Bids in counties where a rival firm also has a plant are 3.6 percent lower than when the firm has no rivals in the county, even controlling for the number of bidders. Bids in adjacent counties where there are no rival plants do not differ from those in the firm's home county, but bids into an adjacent county where a rival firm's plant is located are 3.4 percent higher, controlling for the number of bidders. County boundaries not only serve as a focal point affecting the bidding participation decision, they also affect how aggressively firms bid in these thinner markets.

\section{Additional Anecdotal Evidence of Tacit Collusion}

The significance of county boundaries as a focal point facilitating tacit collusion is very clear from the empirical results on participation and pricing. The general econometric evidence is 
further buttressed by a number of specific examples of bidding patterns so obvious that formal training in econometrics is not necessary. Indeed, a probit analysis of the decision to bid for many firms collapses when county identifier variables are included. Figure 4 illustrates the bidding behavior of four central Kentucky asphalt contractors. The major urban center, Lexington, is located in Fayette County, which is surrounded by Scott, Bourbon, Clark, and Madison Counties. ATS Construction has two asphalt plants in Fayette County, which are indicated in the first panel of Figure 4. The projects that ATS bid on from 2005 to 2007 are indicated by small red dots, and projects within its service area which it feasibly could have served but did not bid on are indicated by small black circles. With only one exception, ATS bid exclusively on projects located in Fayette County, where its asphalt plants are located, ${ }^{45}$ even though there were dozens of projects in close proximity to its plants. ATS refrained from bidding on several projects in adjoining counties that were actually closer to its plants than other projects within Fayette County that were farther away.

Nally \& Gibson's bidding behavior is illustrated in the second panel of Figure 4. Its asphalt plant is located just north of Lexington in Scott County, and the projects on which it did and did not bid are indicated by red dots and black circles. Nally \& Gibson bid exclusively in Scott County. Hinkle Contracting's bidding behavior is illustrated in the third panel. It bid in Bourbon County and in counties north and west of Bourbon County, but never in Scott, Fayette, or Clark counties where the other three companies had asphalt plants. The Allen Company's bidding behavior is illustrated in the fourth panel. Its asphalt plant is located in Madison County,

\footnotetext{
${ }^{45}$ The only project outside Fayette County on which ATS bid on was located in Woodford County, where there are no asphalt plants.
} 
on the border with Clark County. The Allen Company bid in both Clark and Madison Counties, but never in Fayette or Bourbon Counties where ATS and Hinkle had plants.

There are a number of other geographically dispersed oligopoly markets in Kentucky that exhibit the same collusive bidding patterns. For example, Nally \& Haydon Surfacing operates three asphalt plants and bids in four counties in central Kentucky: Washington, Marion, Taylor, and Green. The location of these plants and counties can be seen in Figure 5, which also illustrates asphalt plants belonging to other firms in the surrounding counties. Figure 6 illustrates Nally \& Haydon's bidding behavior - the projects it did and did not bid on. As can be seen, Nally \& Haydon bid exclusively in these four counties. Inspection of the bidding maps of surrounding paving companies reveals that no other firms bid in any of the four counties during the 2005-2007 period. 
Figure 4: Bidding Behavior of Four Firms in Central Kentucky

ATS Construction (plant locations in Fayette County)

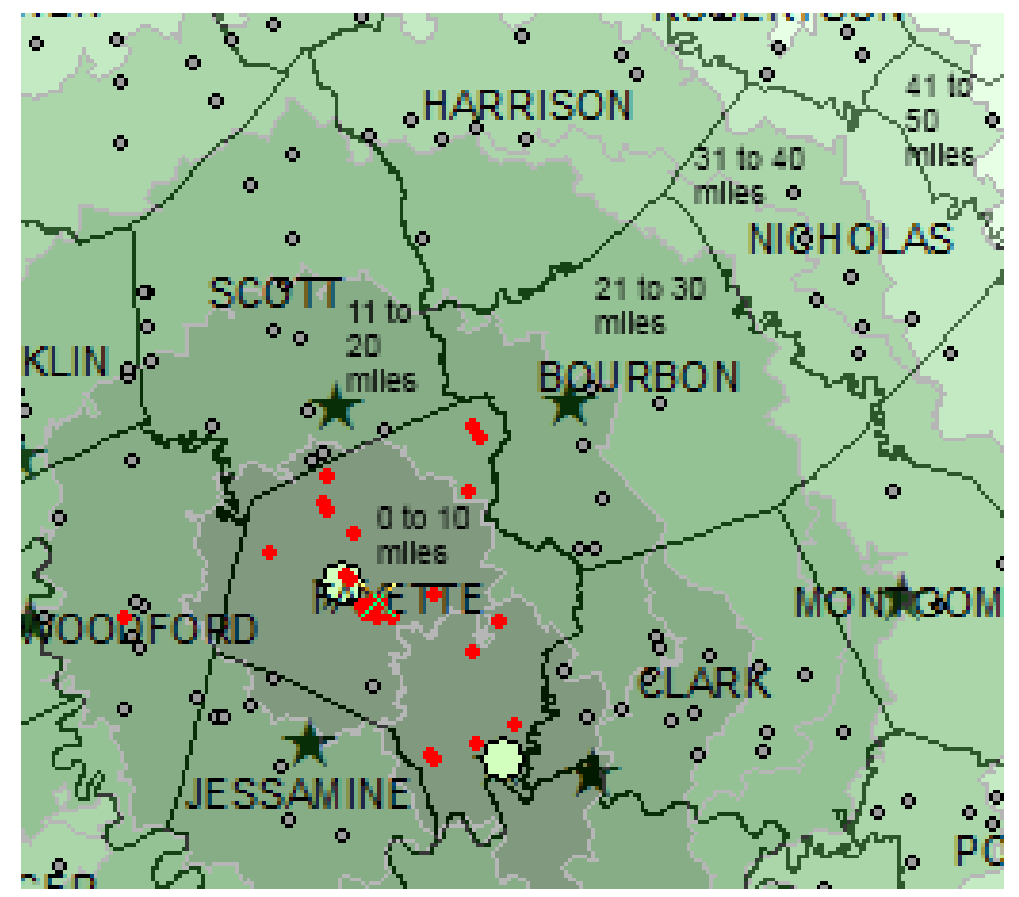

Nally \& Gibson Georgetown (plant location in Scott County)

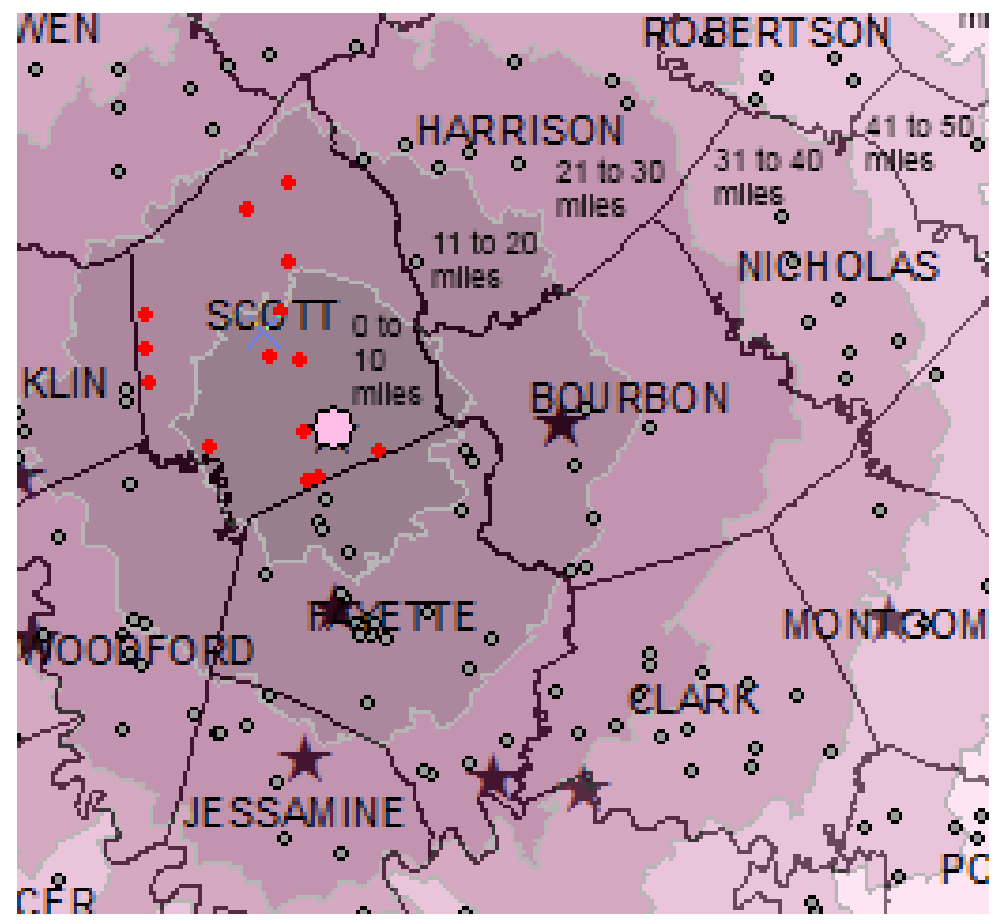


Hinkle Contracting (plant location in Bourbon County)

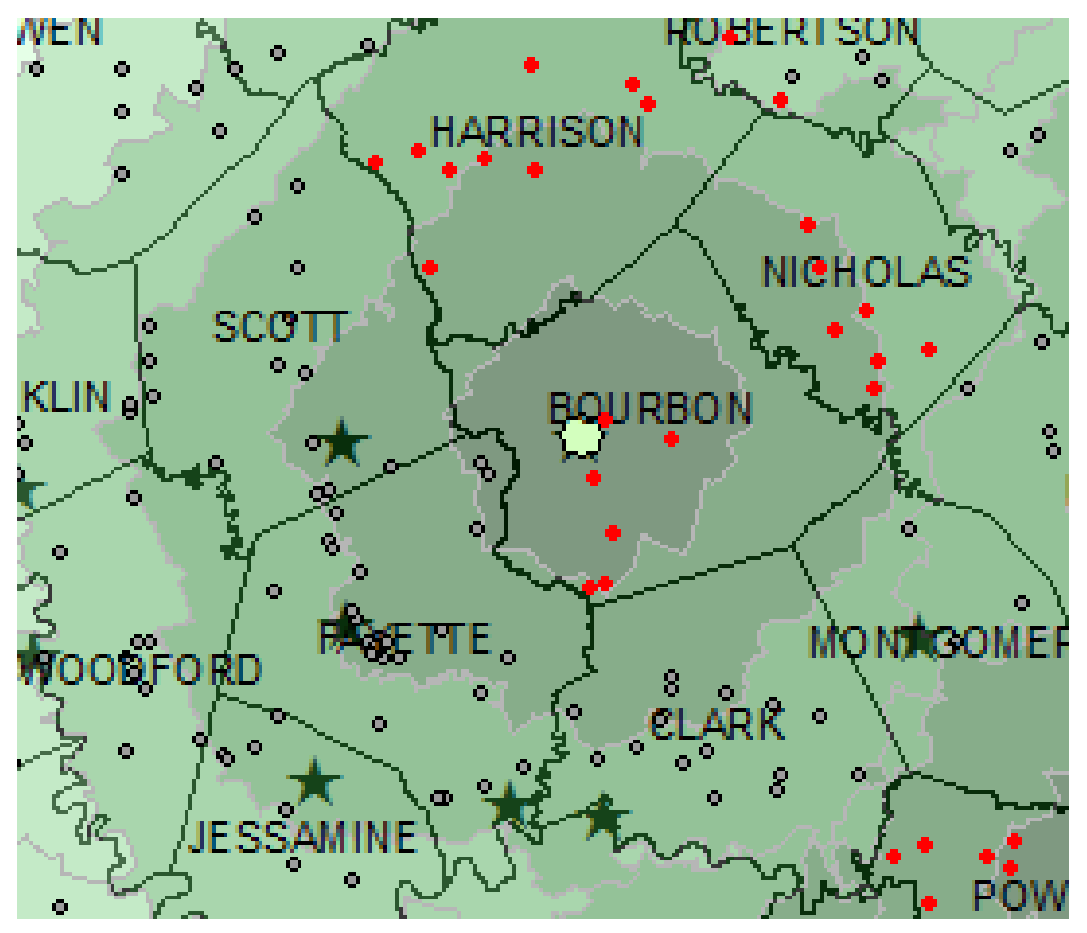

The Allen Company (plant location in Clark County)

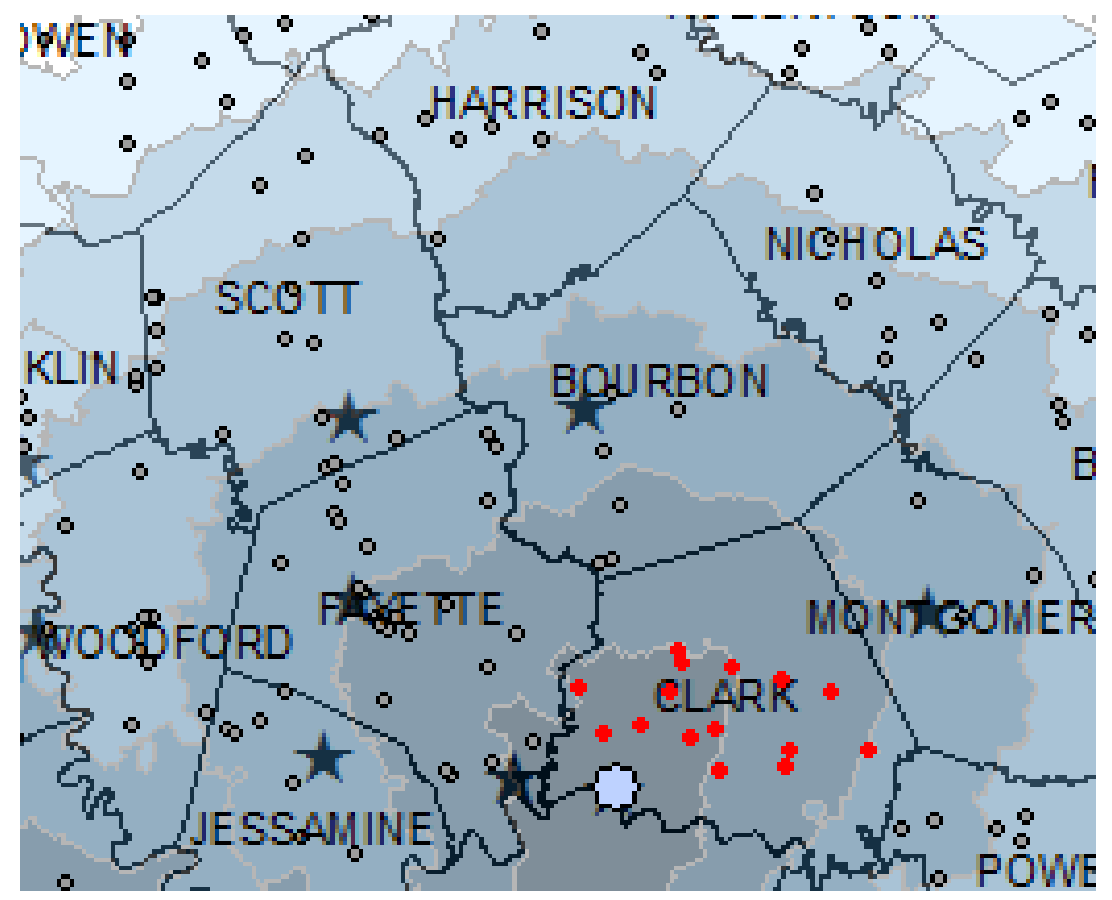




\section{Inducing Cooperation: The Easy Way and the Hard Way}

Our discussion of tacit collusion would not be complete without examples of how rival firms elicit cooperative bidding behavior from one another. One easy and obvious way to eliminate competition is to acquire one's competitors. In the far western corner of Kentucky, H\&G Construction competed with Jim Smith Contracting Company and Murray Paving during the 2005-2007 sample period. As Figure 3 shows, H\&G bid extensively in the 10 far western counties, competing against Jim Smith Contracting in nine of the counties and against Murray Paving in Calloway County. Since Jim Smith Contracting and Murray Paving shared ownership, H\&G Construction was the prototype of a "maverick firm."

\footnotetext{
46 The 2010 U.S. Department of Justice/Federal Trade Commission Merger Guidelines (p. 18) recognize the existence of mavericks - smaller firms that have an outsized effect on competition as a result of their aggressive market behavior. The Guidelines suggest that acquisition of a maverick rival deserves special consideration.
} 
Figure 5: Central Kentucky (District 4) Counties, Firms, and Asphalt Plants

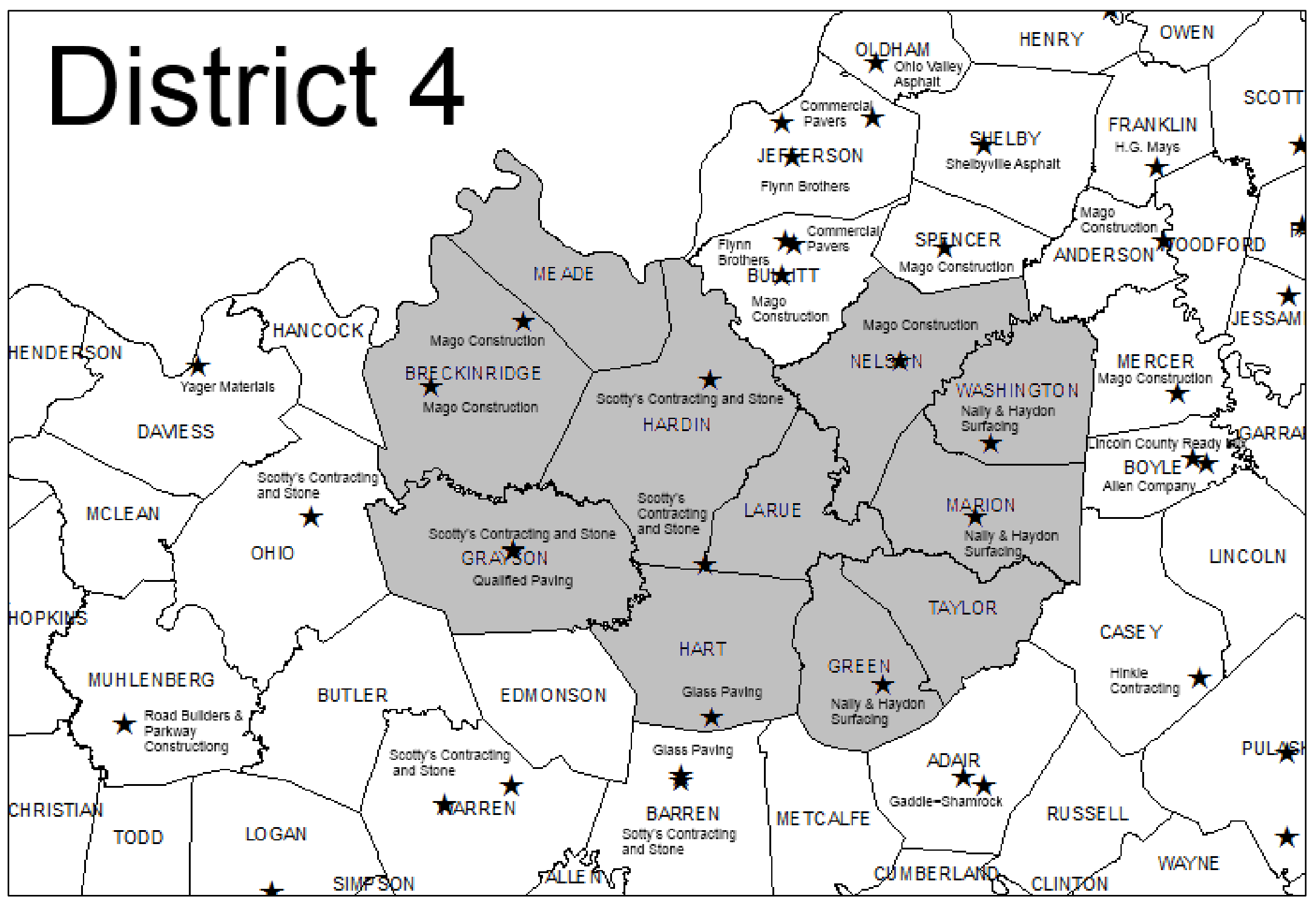


Figure 6: Nally \& Haydon Surfacing Service Area

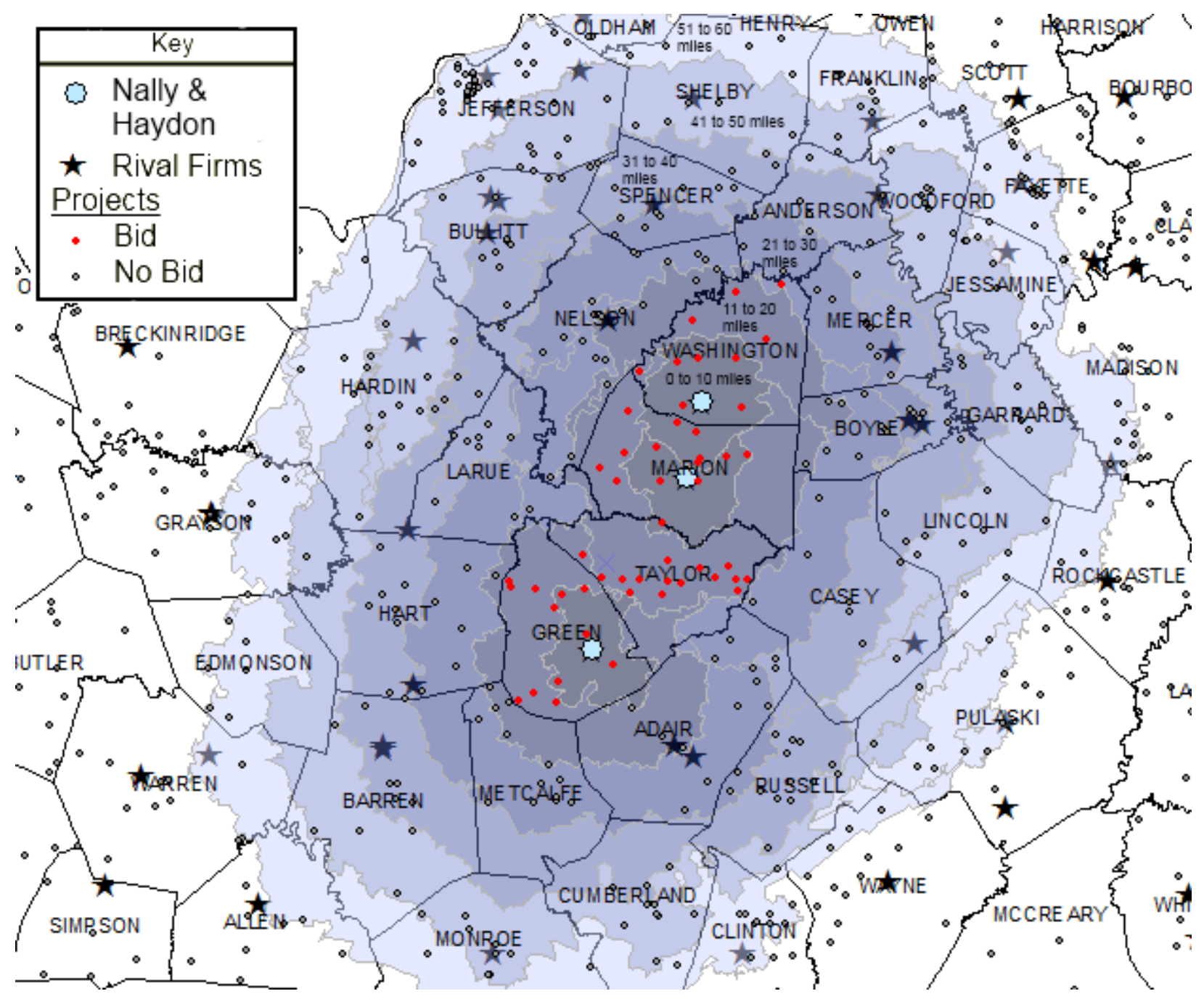

The impact of H\&G's presence in this geographic market is evident from the bidding outcomes. Jim Smith won 72 contracts at an average of 5.96 percent below the state engineer's estimate. Murray won 4 contracts at an average of 1.74 percent below the engineer's estimate. $\mathrm{H} \& \mathrm{G}$ won 14 contracts at an average of 5.64 percent below the engineer's estimate. By way of contrast, the Rogers Group had asphalt plants and was the only bidder in the three countiesCrittenden, Caldwell, and Trigg — ringing the ten western-most counties in the state. Jim 
Smith/Murray Paving did not bid into the Rogers Group's territory, and the Rogers Group reciprocated. As the only bidder in Crittenden, Caldwell, and Trigg counties, the Rogers Group won 50 contracts at an average of 3.24 percent over the engineer's estimate.

Given the nearly complete overlap of H\&G's feasible service territory with Jim Smith/Murray's service territory, a cooperative outcome would not seem to be possible. Absent overt behavior, no obvious solution for collusion suggests itself. No solution, that is, unless the merger of the two firms would not trigger a Hart-Scott-Rodino notification. Indeed that was apparently the case, because in October $2007 \mathrm{Jim}$ Smith Contracting announced that it was acquiring H\&G Construction — an easy solution to the "problem." 47

Another way to induce cooperation in a repeated game is retaliation-moving aggressively against a rival that has abrogated a collusive agreement. Adjacent to the counties served by Nally \& Hayden (illustrated in Figure 5) were Glass Paving and Scotty's Contracting and Stone. Glass Paving had the only asphalt plant in Hart County, while both Glass and Scotty's had plants in Barren County just south of Hart County. Glass Paving was the only bidder in Hart County, while both firms bid in Barren County. Since it had 12 asphalt plants spread around the region, Scotty's bid extensively in surrounding counties as well.

On July 21, 2006, Scotty's Contracting submitted a bid on a large project in Hart County, where it had previously refrained from bidding. Glass Paving was obviously aware that Scotty's might submit a bid, because it deviated from its usual strategy in Hart County of bidding several percentage points above the engineer's estimate. Glass won the bid by going 10 percent below

\footnotetext{
47 "Competing Contractors Combine Companies: H\&G Construction Brings Strength in Bridge-building to Smith Contracting." Paducah Sun, 10/4/07.
} 
the state engineer's estimate for the job, costing it well over $\$ 100,000$ compared with the usual outcome when it was the only bidder.

Glass Paving had the opportunity to express its displeasure in the next KYTC bid letting. On August 11, 2006, Glass retaliated and bid on projects in Edmonson, Metcalfe, and Monroe counties. Neither Glass nor Scotty's had asphalt plants in these counties, but previously Scotty's had been the only bidder. Glass submitted bids that were 4.3 percent above, 6.9 percent below, and 7.3 percent below the engineer's estimate in Edmonson, Metcalfe, and Monroe, counties respectively. Scotty's won all three bids, albeit by going much lower that its previous bids in those counties. Apparently the message was received, because Scotty's did not bid again in Hart County for the remainder of the sample period.

\section{Summary and Conclusions}

Detection and deterrence of collusion are perhaps the primary challenges of antitrust policy. Economists are frequently called upon to play the role of detective in diagnosing collusion in public procurement auctions. Often such collusion is overt and involves determining a winner and the submission of complementary bids. Alternatively, firms may reciprocally refrain from bidding. When the number of bidders is small and there is an obvious focal point for such coordination, firms may successfully suppress competition without direct communication.

In certain geographic markets, the asphalt paving industry lends itself to such tacit collusion. Given the technology of paving roads, firms have limited feasible service territories. Thinner markets may only be able to support a limited number of suppliers. Certain elements of the institutions of highway procurement auctions also create a market environment that facilitates collusive outcomes. 
To determine whether such collusion might occur we collected data on asphalt paving bid lettings by the Kentucky Transportation Cabinet from 2005 to 2007. We analyzed bidding behavior for the 31 registered asphalt contractors in Kentucky. Whether a firm chooses to bid on a project within its feasible service territory was estimated as a function of cost factors such as distance from plant to project, capacity constraints, and scale of the project, as well as strategic factors such as the number of actual or potential rivals. Similarly, how much a firm bids on a project was also estimated as a function of cost and strategic factors. We included county identifier variables to see if firms use county boundaries as focal points to coordinate their bidding.

After estimating these equations for the entire state, we separately analyzed the more competitive regions of Louisville and northern Kentucky and the less competitive regions in the remainder of the state. In choosing whether to bid, firms in competitive regions are primarily influenced by distance and are not deterred by the presence of another likely bidder. Firms in less competitive markets are significantly less likely to bid in an adjacent county where a rival firm has a plant and if another firm has indicated its intention to bid by purchasing an official set of project plans.

In choosing how much to bid, the bid pricing decisions of firms in competitive markets are not significantly different when a firm is bidding in its own or an adjacent county, with or without a rival firm present. In non-competitive markets, however, bid pricing behavior differs considerably according to county type. Bids in counties where a rival firm also has a plant are significantly lower; bids in adjacent counties where there are no rival plants are essentially the same; and bids in adjacent counties where a rival firm has a plant are significantly higher than bids in counties where a firm has the only plant. 
Since 72 of 120 counties in Kentucky have only one asphalt plant, it is not surprising that county boundaries are such an obvious focal point for firms to coordinate bidding activity. The upshot is that 64 percent of asphalt paving contracts attracted only a single bidder from 2005 to 2007. Controlling for other factors, winning bids for single-bid asphalt projects were 9.3 percent higher than winning bids in auctions with three or more bidders in the competitive regions of the state. In noncompetitive regions, the price markup in single-bid auctions was 16.5 percent greater than in auctions where there were three or more bidders. Since Kentucky spent over $\$ 590$ million on asphalt paving contracts during the sample period, the potential savings from increasing competition are substantial.

Several policy changes suggest themselves. First, Adam Smith would probably discourage KYTC-sponsored social functions for contractors on the eve of a bid letting. Second, requiring bidders to publicly declare their intent to bid by publicizing the list of firms that have purchased official plans allows rivals to adjust their bids downward in response to the threat of entry, and thereby reduces the expected gain and hence likelihood of entry by a non-cooperating bidder. It would be simple and easy for KYTC to distribute plans freely to any contractor that could feasibly carry out a given project, and to delay revealing the identity and number of bidders until bids are opened. A final change likely to enhance competition in highway procurement auctions would be to remove the focal point that facilitates collusion, namely, the delineation of projects by county lines. The state could even go one step further and structure projects so that they are within the potential service territories of multiple asphalt plants. 


\section{References}

AASHTO (American Association of State Highway and Transportation Officials). "AASHTO / FHWA Survey on Construction Cost Increases and Competition," Revised May 18, 2006. http://www.fhwa.dot.gov/programadmin/contracts/priccomp.cfm.

AASHTO; National Research Council (U.S.). Transportation Research Board; United States. Army Corps of Engineers and United States Federal Aviation Administration. 2000. HotMix Asphalt Paving Handbook 2000. Washington, D.C.: US Army Corps of Engineers.

Anderson, S. D. and Byron C. Blaschke. 2004. National Cooperative Highway Research Program. American Association of State Highway and Transportation Officials and National Research Council (U.S.). Statewide Highway Letting Program Management. Washington, D.C.: Transportation Research Board.

Bajari, Patrick and Lixin Ye. 2003. "Deciding between Competition and Collusion." The Review of Economics and Statistics, 85(4), 971-89.

Baldwin, Laura H., Robert C. Marshall, and Jean-Francois Richard. 1997. "Bidder Collusion at Forest Service Timber Sales.” Journal of Political Economy 105, 657-699.

Barrus, David R. 2011. "Firm Bidding Behavior in Highway Procurement Auctions: An Analysis of Single-Bid Contracts, Tacit Collusion, and the Financial Impact on Kentucky." University of Kentucky.

Brannman, Lance E. and J. Douglass Klein. 1992. "The Effectiveness and Stability of Highway Bid Rigging." In Empirical Studies in Industrial Organization: Essays in Honor of Leonard W. Weiss, edited by David B. Audretsch and John J. Siegfried, 61-75. Norwell, MA: Kluwer Academic Publishers.

Conley, Timothy G. and Francesco Decarolis. 2016. "Detecting Bidders Groups in Collusive Auctions." American Economic Journal: Microeconomics 8, 1-38.

Cramton, Peter and Jesse A. Schwartz. 2000. "Collusive Bidding: Lessons from the FCC Spectrum Auctions.” Journal of Regulatory Economics 17, 229-252.

De Silva, Dakshina G., Timothy Dunne, and Georgia Kosmopoulou. 2003. “An Empirical Analysis of Entrant and Incumbent Bidding in Road Construction Auctions." The Journal of Industrial Economics, 51(3), 295-316.

De Silva, Dakshina G., Thomas D. Jeitschko, and Georgia Kosmopoulou. 2009. "Entry and Bidding in Common and Private Value Auctions with an Unknown Number of Rivals." Review of Industrial Organization, 35(1-2), 73-93. 
De Silva, Dakshina G., Georgia Kosmopoulou, and Carlos Lamarche. 2009. "The Effect of Information on the Bidding and Survival of Entrants in Procurement Auctions." Journal of Public Economics, 93(1-2), 56-72.

Dixit, Avinash and Susan Skeath. 2004. Games of Strategy, 2nd ed. New York: W. W. Norton \& Co.

Fabra, Natalia. 2003. "Tacit Collusion in Repeated Auctions: Uniform Versus Discriminatory." The Journal of Industrial Economics, 51(3), 271-93.

Feinstein, Jonathan S.; Michael K. Block, and Frederick C. Nold. 1985. "Asymmetric Information and Collusive Behavior in Auction Markets." The American Economic Review, 75(3), 441-60.

Fraas, Arthur G. and Douglas F. Greer. 1977. "Market Structure and Price Collusion: An Empirical Analysis.” Journal of Industrial Economics, (September). 21-44.

Funderburk, Dale R. 1974. "Price-Fixing in the Liquid Asphalt Industry: Economic Analysis vs. the 'Hot Document."' Antitrust Law and Economics Review 7, 61-74.

Graham, Daniel A. and Robert C. Marshall. 1987. "Collusive Bidding Behavior at Single-Object Second-Price and English Auctions." Journal of Political Economy 95:1217-39.

Green, Edward J., Robert C. Marshall, and Leslie M. Marx. 2015. "Tacit Collusion in Oligopoly." In the Oxford Handbook on International Antitrust Economics, edited by Roger Blair and Daniel Sokal.

Griffith, Ryan. 2010. Personal interview. Frankfort, KY: Kentucky Transportation Cabinet.

Harrington, Joseph E. 2008. "Detecting Cartels." In Handbook of Antitrust Economics, edited by Paolo Buccirossi, 213-58. The MIT Press.

Hendricks, Ken, R., Preston McAfee, and Michael A. Williams. 2015. "Auctions and Bid Rigging." In the Oxford Handbook on International Antitrust Economics, edited by Roger Blair and Daniel Sokal.

Isaac, R. Mark and James M. Walker. 1985. "Information and Conspiracy in Sealed Bid Auctions." Journal of Economic Behavior and Organization 6, 139-159.

Ishii, Rieko. 2009. "Favor Exchange in Collusion: Empirical Study of Repeated Procurement Auctions in Japan." International Journal of Industrial Organization 27, 137-144.

Jofre-Bonet, Mireia and Martin Pesendorfer. 2003. "Estimation of a Dynamic Auction Game." Econometrica, 71(5), 1443-89. 
Kentucky Transportation Cabinet. 2004. "Statewide Transportation Improvement Plan for Fy 2005-2007," Division of Program Management, Frankfort, KY: Kentucky Transportation Cabinet, August 16, 2010, http://transportation.ky.gov/progmgmt/stip/stip1.htm.

Klemperer, Paul. 2002. "What Really Matters in Auction Design.” Journal of Economic Perspectives 16, 169-189.

Klemperer, P. D. 2004. Auctions: Theory and Practice. Princeton: Princeton University Press.

Lanzillotti, Robert. 1996. "The Great Milk Conspiracies of the 1980s." Review of Industrial Organization, 2(August), 413-58.

Lawson, Leonard. "Statement of Leonard Lawson, Mountain Enterprises, August 5, 1983.”

Lee, In K. 1999. "Non-Cooperative Tacit Collusion, Complementary Bidding and Incumbency Premium." Review of Industrial Organization 15, 115-134.

Lee, In Kwon and Kyungdong Hahn. 2002. "Bid-Rigging in Auctions for Korean Public Works Contracts and Potential Damage." Review of Industrial Organization 21, 73-88.

Levenstein, Margaret and Valerie Suslow. 2015. "Cartels and Collusion-Empirical Evidence." In the Oxford Handbook on Internationsl Antitrust Economics, edited by Roger Blair and Daniel Sokal.

Lewis, Matthew S. 2015. "Odd Prices at Retail Gasoline Stations: Focal Point Pricing and Tacit Collusion.” Journal of Economics \& Management Strategy 24, 664-685.

Marshall, Robert C. and Leslie M. Marx. 2009. "The Vulnerability of Auctions to Bidder Collusion.” Quarterly Journal of Economics, 883-910.

McAfee, R. Preston and John McMillan. 1987. "Auctions and Bidding." Journal of Economic Literature 25, 699-738.

Page, William H. 2016. "Tacit Agreement under Section 1 of the Sherman Act." Antitrust Law Journal (forthcoming).

Pesendorfer, Martin. 2000. "A Study of Collusion in First-Price Auctions." The Review of Economic Studies, 67(3), 381-411.

Porter, Robert H. 2005. "Detecting Collusion.” Review of Industrial Organization, (March). 147167.

Porter, Robert H. and J. Douglas Zona. 1993. "Detection of Bid Rigging in Procurement Auctions." The Journal of Political Economy, 101(3), 518-38. 
Porter, Robert H. and J. Douglas Zona. 1999. "Ohio School Milk Markets: An Analysis of Bidding." The RAND Journal of Economics, 30(2), 263-88.

Price, Michael K. 2008. "Using the Spatial Distribution of Bidders to Detect Collusion in the Marketplace: Evidence from Timber Auctions." Journal of Regional Science 48 (2): 399417.

Ryan, Sean. 2004. “Wisdot Seminar Draws 270,” The Daily Reporter (Milwaukee, WI), March $10,2010$.

Scott, Frank A. 2000. "Great School Milk Conspiracies Revisited." Review of Industrial Organization 17 (November): 325-41.

Smith, Adam. The Wealth of Nations. Chicago: University of Chicago Press, 1976 edition.

Sniffen, Michael J. 1982. "Highway Bid-Rigging Investigation Expanded to Five New States," The Associated Press.

Sniffen, Michael J. 1984. "Federal Highway Bid-Rigging Probe Expands into 29th State," The Associated Press.

Stigler, George. 1964. “A Theory of Oligopoly.” Journal of Political Economy 72, 44-61.

U.S. General Accounting Office. 1990. Changes in Antitrust Enforcement Policies and Activities, GAO/GGD-91-2, (October).

Werden, Gregory J. 2004. "Economic Evidence on the Existence of Collusion: Reconciling Antitrust Law with Oligopoly Theory." Antitrust Law Journal 71, 719-800.

Yao, Dennis A. and Susan S. DeSanti. 1993. "Game Theory and the Legal Analysis of Tacit Collusion.” The Antitrust Bulletin, 38(113). 